Gravity with zeros: estimating trade potential of CIS countries

Oleksandr Shepotylo (Kyiv School of Economics and Kyiv Economics Institute) 


\title{
Gravity with zeros: estimating trade potential of CIS countries
}

\author{
Oleksandr Shepotylo \\ Kyiv School of Economics and Kyiv Economics Institute \\ Vul. Yakira, 13 Office 326 \\ Kiev, Ukraine 04119 \\ oshepotylo@eerc.kiev.ua
}

\begin{abstract}
Arguably, the Commonwealth of Independent States (CIS) countries are not as integrated into the world markets as the EU countries or Southeast Asian countries. Trade flows of the CIS countries are not well diversified in terms of either trading partners or composition of exports. In order to compare the degree of export diversification of the CIS countries relative to other countries, we employ the gravity model that proved to be very successful in explaining geographical patterns of trade across countries. The gravity equation is estimated 'out-of-sample', meaning that we do not include data on trade flows of the CIS countries in the sample while calculating parameters of the gravity equation. Egger (2002) argued forcefully that the 'in-sample' estimation of the trade potential based on the deviation of residuals from the linear prediction is incorrect because large deviations of residuals in the gravity equation based on the in-sample method is not evidence of large deviations of trade from its potential, but rather an indicator of the model misspecification. In addition, we explicitly deal with the problems of zero trade flows and firm's heterogeneity that become more severe at higher levels of disaggregation such as at the level of sectors of the economy.
\end{abstract}

Keywords: gravity model, trade potential, out-of-sample predictions

JEL categories: F12, F14, F17 


\section{Introduction}

A gravity equation has been widely used in empirical analyses of the determinants of international trade flows since the early 1960s. In fact, the literature that uses the gravity equation is very rich. Tinbergen (1962) published the first empirical paper that estimated international trade flows using the gravity equation. After Anderson (1979) laid out the theoretical foundation of the gravity equation, it became widely accepted as a standard tool in empirical research. Recently, the literature on the gravity equation has concentrated on estimating determinants of bilateral trade flows such as common currency (Rose, 2000), international borders (McCallum, 1995; Anderson and van Wincoop, 2003) as well as on methodological issues (Egger 2000, 2002; Baldwin and Taglioni 2006).

Until recently, it was typically estimated using aggregated data, assuming symmetric trade costs and ignoring zero trade flows. As a result, a typical empirical gravity model ignores several important stylised facts about trade flows such as the prevalence of zeros in the bilateral trade matrix in disaggregated data, the asymmetry of trade between country-pairs, and the adjustment of trade at extensive margins. However, these stylised facts are very important pieces of information that, if appropriately accounted for, improve the ability of the gravity model to explain trade flows and remove some econometric biases caused by the misspecification of the standard gravity model. 
First, ignoring zeros in the gravity equation causes a selection bias because the same factors that determine trade volumes also influence the selection of firms as exporters and non-exporters. Second, unobserved firmlevel heterogeneity and unaccounted fixed costs of exporting create substantial asymmetries between trading partners and bias estimators of the coefficients of the gravity equation because of the correlation of errors with explanatory variables. Finally, disaggregated trade data allow us to look at trade adjustments along both the extensive and intensive margins and to predict changes in the composition of trade at the level of sectors of the economy that is essential for evaluating the effect of policy changes on trade and development.

The selection bias and especially the asymmetry bias have been largely ignored in the empirical literature that employs the gravity model. However, recent developments in the theoretical literature have demonstrated that the stylised facts can be generated within a model of imperfect competition with heterogeneous firms that optimally select markets where they sell their products facing country- and pair-specific fixed costs (Melitz, 2003). Recent empirical works by Helpman, Melitz and Rubinstein (2008) and Martin and Pham (2008) have started to fill the gap between theory and practice by incorporating the selection process into the estimation procedure, but considerable efforts are yet to be made to fully integrate new theoretical advances into the standard toolbox of international trade. 
This paper develops a gravity model of trade at the industry level that takes into account selection and asymmetry biases. ${ }^{1}$ The heterogeneity of firms at an industry level is explicitly modelled. Only the most productive firms are engaged in international trade. The fixed costs of exporting vary systematically across industries and country-pairs due to industry- and pair-specific factors such as the fixed trade costs of exporting and linguistic differences. In addition, there are country-specific fixed costs related to the regulatory quality of institutions in a country. A combination of the firm-level heterogeneity and fixed costs of exporting leads to industry-level heterogeneity and trade asymmetries between the trading pairs.

The model is estimated for a panel of 135 countries from 2000--2006 using the Hausman--Taylor (1981) technique. It allows retaining the timeinvariant exogenous country- and pair-specific variables while dealing with unobserved heterogeneity (Egger, 2002). Accounting for the selection and asymmetry biases leads to the consistent estimation of the coefficients of the gravity equation and helps to predict the effect of policy changes on trade.

The industry-level model that matches important features of actual trade flows is useful in many applications. It allows us to estimate the trade potential of a country that lifts trade restrictions and moves to deep trade liberalisation. Correcting for the selection process to remove the bias that works through fixed costs is important because deep trade liberalization lowers non-tariff barriers

\footnotetext{
${ }^{1}$ The only paper that uses a similar methodology to derive the gravity equation at the industry level is Manova (2006), who studied the impact of financial constraints on bilateral trade flows.
} 
and reduces the fixed costs of exporting, which in turn translates into substantial adjustments at the extensive margins. In addition, the industry-level gravity model of trade can be used to generate trade flows when data are missing, as is usually the case for trade between the regions within a country. The generated regional trade matrix can be used further in computational general equilibrium (CGE) models that evaluate the effect of industry- and regional-levels of trade policies (see, e.g., Harrison, Rutherford and Tarr, 1997; Rutherford and Tarr, 2008).

As an application of the developed methodology, the ability of the model to predict the geographic and industry composition of trade is tested using a sample of CIS countries. Arguably, the CIS region is not as integrated into the world market as the EU or Southeast Asian countries. Its trade is not as well diversified in terms of both trading partners and industry composition. Therefore, a considerable gap between potential and actual trade can be observed. Using an 'out-of-sample' methodology (Egger, 2000), the trade matrix of potential exports of CIS countries at the industry level is generated and then compared with the actual trade matrix.

The results show that the trade patterns of CIS countries are largely in line with what the gravity model predicts. The predicted geographic and industry composition of exports match the real data quite successfully at both the extensive and intensive margins. Nevertheless, there are important export flow distortions in some countries and industries that indicate a smaller degree of geographical and industrial diversification than would be expected from the 
gravity model. The CIS countries tend to overtrade with other CIS countries, and they export disproportionally more in the resource-extraction-oriented sectors. At the same time, the CIS countries export consistently less than expected in both the agriculture and forestry industry and the food industry, which might indicate additional external and internal trade barriers that are particular to these two industries.

The rest of this paper proceeds as follows. In the second section, we discuss some stylised facts about zero trade flows at the industry level. In the third section, we derive the gravity model at industry-level aggregation. In the fourth section, we present the data and discuss the empirical strategy of the consistent estimation of the model. In the fifth section, we discuss the predicted regional trade flows. Finally, section six concludes and discusses directions for further research.

\section{Industry Level Exports: First Glance at the Data}

Modelling and estimating the gravity equation at an industry-level aggregation poses several problems that should be addressed in order to obtain consistent results. One of the major features of international trade flows is a large number of zeros that systematically vary from one industry to another and, in general, exceed the number of non-zero trade flows even for trade data at industry-level aggregation. In this section, we focus on the main features of industry-level trade flows and discuss cross-industry variations in the data.

The investigated sample includes 136 source countries and 157 destination countries for the period 2000--2006. The export data was acquired from the 
United Nations Commodity Trade Statistics database (Comtrade) at the level of Global Trade Analysis Project (GTAP) sectors and is further aggregated into 10 industries according to the mapping presented in Table $1 .^{2}$ Potentially, 21,216 positive bilateral exports per industry per year can be observed. However, as shown in Table 2, zeros account for more than one-half of all the observations. The sample has 646,438 positive trade values out of a possible $1,485,120$ bilateral pairs, which accounts for only 44 percent of the sample. The share of positive exports varies considerably across industries - from 25 percent of positive flows in energy resources to 53 percent of positive flows in the manufacturing n.e.c. industry, as presented in the last column of Table 2.

Looking at intensive margins of trade, the average value of bilateral exports varies significantly across industries as well. The average export value is equal to US\$23 million in the agriculture and forestry industry, US\$64 million in metallurgy, and US\$137 in electronic equipment, as reported in the second column of Table 2. Overall, the average value of exports at the industry level is equal to US\$82 million

Since there are significant and systematic variations of export patterns across industries, a satisfactory model of bilateral exports should explain the substantial heterogeneity of exports at the industry level at both the extensive and intensive margins. The next section presents a theoretical model that

\footnotetext{
${ }^{2}$ We acquired data for 42 GTAP sectors, excluding service sectors. Further aggregation to 10 industries is done for ease of presentation, but is not necessary from theoretical and computational standpoints.
} 
captures some important empirical regularities and derives a gravity equation for further empirical analysis.

\section{Methodology}

A modified version of the Helpman, Melitz and Rubinstein (2008) model is developed in this section. It explains the mechanism of selection into exporting and non-exporting firms by modelling the export decisions of heterogeneous firms that differ in their productivity. Exporting is costly due to the fixed costs of exporting, which includes setting up a distribution network, adjusting to local preferences, and dealing with country-specific legal requirements. The countrypair-specific fixed costs influence the decision of firms to enter the market; only a subset of firms is productive enough to engage in international trade and to compete in foreign markets. The cut-off point separating exporters from nonexporters varies from one country-pair to another and from one industry to another. Hence, the model generates a pattern of bilateral exports that are industry specific and non-symmetric for a given country-pair. Thus, the model is able to explain why a majority of firms from a given country may find it profitable to export to one destination and not to export at all to another destination due to the country-pair specificity of the fixed costs.

The methodology is different from that of Helpman, Melitz and Rubinstein (2008) in several important ways. First, it is a model at the industry level that allows for industry-level heterogeneity in trade costs. ${ }^{3}$ Second, the

\footnotetext{
${ }^{3}$ Hummels (1999) studied trade costs for 3,000 goods for New Zealand and Latin American imports and over 15,000 goods for US imports and found that trade costs vary significantly across industries. In particular, freight costs for manufacturing are lower than for commodities and agricultural products. For example, importing fruits and vegetables costs
} 
source of uncertainty in the model comes from unobservable factors in the multilateral resistance term in addition to unobservable factors in the trade costs. The unobservable country- and pair-specific factors can be correlated with some of the explanatory variables, and the resulting endogeneity is controlled for by applying the Hausman--Taylor (1981) method that exploits time and cross-country variations in the data. The use of panel data instead of cross-sectional analysis allows us to remove some biases stemming from unobserved industry and country-pair heterogeneity and to estimate the parameters of the model with greater precision. Finally, this paper develops a methodology that predicts industry-level trade flows using data available from general sources. This goal leads to additional restrictions on the data and estimation method, which are discussed later in the paper.

\subsection{Model of Bilateral Export}

Consider the Dixit--Stiglitz model of monopolistic competition with consumer preferences identical and homothetic across countries described, for example, by Feenstra (2003). ${ }^{4}$ Each country $i=1 \ldots C$ has $N_{k}^{i}$ firms that produce differentiated products in industries $k=1, \ldots, K$. Let $c_{k l}^{i j}$ denote total consumption in country $j$ of a good $l$ that is produced by sector $k$ in country $i$.

approximately 15 percent of the value of shipment, while importing road vehicles costs 2.1 percent.

${ }^{4}$ Chamberlin (1933) first introduced the main components of the monopolistic competition model. Dixit and Stiglitz (1977) and Krugman (1979) brought in the love of variety into the model. 


\subsubsection{Consumers}

A representative consumer located in country $j$ has the utility function of the following form:

$U^{j}=\sum_{k=1}^{K}\left(\sum_{l \in B_{k}^{j}} c_{k l}^{j \frac{\sigma-1}{\sigma}}\right)^{\theta_{k}}$

where $\sigma>1$ is the elasticity of substitution across different products. $\theta_{k}$ is the

expenditure share of industry $k$ in total consumption. $B_{k}^{j}$ is the set of industry $k$ goods that are available for consumption in country $j$. The representative consumer maximizes equation (1) with respect to his budget constraints:

$Y^{j}=\sum_{k=1}^{K} \sum_{l \in B_{k}^{j}} p_{k l}^{j} c_{k l}^{j}$

The optimal consumption derived from the optimization problem is:

$c_{k l}^{j}=\frac{\theta_{k} Y^{j}}{P_{k}^{j}}\left(\frac{p_{k l}^{j}}{P_{k}^{j}}\right)^{-\sigma}$

where

$P_{k}^{j}=\left(\sum_{l \in B_{k}^{l}}\left(p_{k l}^{j}\right)^{1-\sigma}\right)^{\frac{1}{1-\sigma}}$

is the price index of industry $k$. 


\subsubsection{Producers}

A country $i$ firm produces one unit of output with $w^{i} a$ units of labour. ${ }^{5} w^{i}$ is country specific, reflecting the differences in technology and factor prices, and $a$ is a firm-specific parameter with the cumulative distribution function $G_{k}(a)$ over support $\left[a_{k \min }, a_{k \max }\right]$. Each firm is a monopolist over the production of a distinct good, but is small relative to the size of the market. A standard formula for monopolistic pricing implies that the firm charging the mill price as a constant mark-up over the marginal cost:

$p^{i}=\frac{\sigma}{\sigma-1} w^{i} a$

There are variable and fixed costs of delivering products to consumer

markets that vary across industries. $T_{k}^{i j}$ is a melting iceberg transportation cost with $T_{k}^{i j}>1, T_{k}^{i i}=1 . F_{k}^{i j}$ is a fixed cost of exporting that is country-pair and industry specific with $F_{k}^{i j}>0, F_{k}^{i i}=0$. If the firm chooses to export its product to country $j$, consumers in country $j$ pay $p_{k}^{i j}=\frac{T_{k}^{i j} \sigma w^{i} a}{\sigma-1}$. It follows that the profit of the firm exporting to country $j$ is:

$\pi_{k}^{i j}(a)=\frac{\theta_{k}}{\sigma}\left[\frac{\sigma T_{k}^{i j} w^{i} a}{(\sigma-1) P_{k}^{j}}\right]^{1-\sigma} Y^{j}-F_{k}^{i j}$

\footnotetext{
${ }^{5}$ We consider a partial equilibrium model with fixed capital during the period being investigated. Labour is the only input that is perfectly mobile across industries, but immobile across countries.
} 
The firm exports only if it receives positive operating profits, which is

more likely if the productivity of the firm $\left(\frac{1}{a}\right)$ is high, the input price $\left(w^{i}\right)$ is low, and the fixed costs of exporting $\left(F_{k}^{i j}\right)$ are low. The marginal firm that exports to country $j$ satisfies the following criteria:

$\pi_{k}^{i j}\left(a_{k}^{i j}\right)=0 \Leftrightarrow \frac{\theta_{k}}{\sigma}\left[\frac{\sigma T_{k}^{i j} w^{i} a_{k}^{i j}}{(\sigma-1) P_{k}^{j}}\right]^{1-\sigma} Y^{j}=F_{k}^{i j}$

\subsubsection{Industry level aggregation}

Out of $N_{k}^{i}$ firms that operate in country $i$ in industry $k$, only $N_{k}^{i} G\left(a_{i j}\right)$ firms export to country $j$. The aggregate export in industry $k$ from exporter $i$ to country $j$ is:

$X_{k}^{i j}=N_{k}^{i} G\left(a_{k}^{i j}\right) E\left(p_{k}^{i j}(a) c_{k}^{i j}(a) \mid \pi_{k}^{i j}(a)>0\right)=N_{k}^{i} \theta_{k} Y^{j} V_{k}^{i j}\left(\frac{\sigma T_{k}^{i j} w^{i}}{(\sigma-1) P_{k}^{j}}\right)^{1-\sigma}$

if $a_{k}^{i j}>a_{\min }$

and $X_{k}^{i j}=0$ otherwise, where $V_{k}^{i j}=\int_{a_{\min }}^{a_{k}^{i j}} a^{1-\sigma} d G_{k}(a)$.

The equation can be simplified further by using the equilibrium constraint on the output of sector $k$ produced by country $i$ :

$$
Y_{k}^{i}=\sum_{j=1}^{C} X_{k}^{i j}=N_{k}^{i} \theta_{k}\left(\frac{\sigma w^{i}}{\sigma-1}\right)^{1-\sigma} \sum_{j=1}^{C}\left(\frac{T_{k}^{i j}}{P_{k}^{j}}\right)^{1-\sigma} Y^{j} V_{k}^{i j}
$$

which leads to the following export equation: 
$X_{k}^{i j}=s_{k}^{i} Y^{i} Y^{j} V_{k}^{i j} \frac{\left(\frac{T_{k}^{i j}}{P_{k}^{j}}\right)^{1-\sigma}}{\sum_{j=1}^{C}\left(\frac{T_{k}^{i j}}{P_{k}^{j}}\right)^{1-\sigma} Y^{j} V_{k}^{i j}}$

\subsection{Parameterization and Estimation Methodology}

\subsubsection{Gravity equation}

Trade costs associated with the shipping of a unit of good from country $i$ to country $j$ are modelled by assuming the commonly used functional form: $\left(T_{k}^{i j}\right)^{\sigma-1}=\left(d i s t^{i j}\right)^{\rho_{k}} \exp \left(Z \gamma_{k}\right)$

where dist ${ }^{i j}$ is the distance between countries $i$ and $j$, and $Z$ is a set of additional variables that determine trade costs, such as the contiguity dummy, landlocked dummies - whether country $i$ or $j$ is landlocked, the interior distances of countries $i$ and $j$, and whether the countries are located on the same continent.

$\gamma_{k}$ is the vector of coefficients associated with the set of variables $Z$.

Taking the logs of both sides of equation (9) and substituting for $T_{k}^{i j}$ yields:

$\ln X_{k t}^{i j}=\ln s_{k t}^{i}+\ln Y_{t}^{i}+\ln Y_{t}^{j}+\ln V_{\mathrm{kt}}^{\mathrm{ij}}-\rho_{k} \ln d i s t^{i j}-Z \gamma_{k}-(1-\sigma) \ln P_{k t}^{j}-\ln M R T_{k t}^{j}, \mathrm{t}=1,2 \ldots \mathrm{T}$

where $\ln M R T_{k t}^{j}$ is the multilateral resistance term, an integral measure of trade barriers of a country vis-à-vis all its trading partners (Anderson and van Wincoop, 2003), which accounts for the endogenous and simultaneous determination of trade flows across all countries. 


\subsubsection{Selection of firms}

Define a latent variable as:

$\Psi_{k t}^{i j}=\frac{\frac{\theta_{k}}{\sigma}\left[\frac{\sigma T_{k}^{i j} w_{t}^{i} a_{\min }}{(\sigma-1) P_{k t}^{j}}\right]^{1-\sigma} Y_{t}^{j}}{F_{k t}^{i j}}$

A positive export is observed if $\Psi_{k t}^{i j} \geq 1$. Conditional on a positive export,

$V_{k}^{i j}$ is an increasing function of $\Psi_{k t}^{i j}$ for an arbitrary $G_{k}(a)$ (see Helpman,

Melitz and Rubinstein, 2008). Suppose that fixed costs have the following

functional form $F_{k t}^{i j}=\exp \left(\phi_{k}^{i}+\phi_{k}^{j}+\kappa \phi_{k}^{i j}+\theta_{k t}^{i j}\right)$, where $\phi^{i}$ represents fixed costs specific to the exporting country, $\phi^{j}$ represents fixed costs specific to the importing country, $\phi^{i i}$ represents country-pair-specific fixed costs, and $\theta_{k t}^{i j}$ represents country-pair-specific random components distributed as $N\left(0, \sigma_{k \theta}^{2}\right)$.

Finally, let the price index evolve as $P_{k t}^{j}=P_{k}^{j} \exp \varphi_{t}$.

Taking logs of both sides of equation (11) yields:

$$
\begin{array}{r}
\psi_{k t}^{i j}=\zeta_{0}^{k}+\ln Y_{t}^{j}-\rho_{k} \ln d i s t^{i j}-Z \gamma_{k}+(1-\sigma) \ln w_{t}^{i} \\
-d^{j}-(1-\sigma) \varphi_{t}-\phi_{k}^{i}-\phi_{k}^{j}-\kappa \phi_{k}^{i j}+\theta_{k t}^{i j}
\end{array}
$$

where $d^{j}=\ln P_{k}^{j}$.

Both sides of equation (12) are divided by $\sigma_{k \theta}$ to normalize the selection equation:

$$
\begin{aligned}
\rho_{k t}^{i j} & =\operatorname{Prob}\left(\mathrm{X}_{\mathrm{kt}}^{\mathrm{ij}}>0 \mid \Psi_{\mathrm{kt}}^{\mathrm{ij}}\right)=\Phi\left(\zeta_{0}^{k}+\ln Y_{t}^{j}-\rho_{k} \ln d i s t^{i j}-Z \gamma_{k}\right. \\
& \left.+(1-\sigma) \ln w_{t}^{i}-d^{j}-(1-\sigma) \varphi_{t}-\phi^{i}-\phi^{j}-\kappa \phi^{i j}\right)
\end{aligned}
$$


Finally, notice that a predicted probability of positive exports from country $i$ to country $j$ in industry $k$ is $\hat{\rho}_{k t}^{i j}$, and the estimated value of the latent variable is $\hat{\psi}_{k t}^{i j}=\Phi^{-1}\left(\hat{\rho}_{k t}^{i j}\right)$.

\subsubsection{Multilateral resistance term}

The multilateral resistance term $\ln M R T_{k}^{i}$ is not observable, and according to theory is simultaneously determined for all countries. A traditional approach to deal with the multilateral resistance term is by introducing country fixed effects or pair fixed effects (see Baldwin and Taglioni, 2006, for a discussion on the usage of fixed effects in the gravity equation). However, it limits the ability of the model to generate 'out-of-sample' predictions because of the inability to estimate country fixed effects for exporting countries not included in the estimation sample. We assume that the MRT can be approximated - if parameter $\sigma$ is close to two and that distance contributes the most to the trade costs - by the following expression:

$\ln M R T_{k t}^{i}=\ln \left(\sum_{j=1, j \neq i}^{C} \frac{P_{t}^{j} Y_{t}^{j}}{d i s t_{i j}}\right)+u_{k}^{i}+\varepsilon_{k t}^{i}$

where $u_{k}^{i} \sim N\left(0, \sigma_{u}^{2}\right)$ is a time-invariant, unobservable random effect that can be correlated with some of the explanatory variables, and $\varepsilon_{k t}^{i} \sim N\left(0, \sigma_{\varepsilon}^{2}\right)$ is an idiosyncratic error term uncorrelated with the explanatory variables. 


\subsection{Identification Strategy}

First, equation (11) is estimated using the standard probit model that includes time fixed effects and destination-country fixed effects. For better identification, several variables that affect fixed costs, but have no effect on the volume of trade (and thus are included in the selection equation, but not the gravity equation) are needed. Based on the results from Helpman, Melitz and Rubinstein (2008) and Martin and Pham (2008), we control for pair-specific fixed effects by including a common language dummy as one of the variables that affects the decision of a firm to trade, but has no significant impact on the volume of trade. To control for country-specific fixed costs, we include regulatory quality indices for both reporting and partner countries as factors that are proportional to the fixed costs of trade and therefore belong to the selection equation. ${ }^{6}$ Helpman, Melitz and Rubinstein (2008) also suggest a common religion dummy variable to control for pair-specific trade costs. However, unlike an official language, most countries have different religious groups and the composition can be very complicated, which makes it rather difficult to come up with a clean binary classification of country-pairs in terms of their religious similarities.

At the second step, $\ln V_{k t}^{i j}$ is approximated by the polynomial of degree 3 by including the estimated values of the latent variable and its second and third

\footnotetext{
${ }^{6}$ The regulatory quality index from governance matters (Kaufmann, Kraay and Mastruzzi, 2007) measures the ability of the government to formulate and implement sound economic policies that promote private sector development.
} 
powers, $\ln V_{k t}^{i j} \approx \sum_{m=1}^{3} b_{m}\left(\hat{\psi}_{k t}^{i j}\right)^{m}, \hat{\psi}_{k t}^{i j}=\Phi^{-1}\left(\hat{\rho}_{k t}^{i j}\right)$, into the gravity equation (10). As shown by Helpman, Melitz and Rubinstein (2008), the polynomial of degree 3 is a sufficiently flexible and accurate approximation of the underlying unknown distribution. Finally, the Hausman--Taylor method is applied to estimate the gravity equation by treating the export share of the industry and the GDPs of both countries as endogenous variables that are correlated with industry- and pair-specific error components:

$\ln X_{k t}^{i j}=\ln s_{k t}^{i}+\ln Y_{t}^{i}+\ln Y_{t}^{j}+\rho_{k} \ln d i s t^{i j}+Z \gamma_{k}+\sum_{m=1}^{3} b_{k m}\left(\hat{z}_{k t}^{i j}\right)^{m}+\ln \left(\sum_{j=1, j \neq i}^{C} \frac{P_{t}^{j} Y_{t}^{j}}{d i s t_{i j}}\right)+d_{k}^{j}+\varphi_{t}+u_{k}^{i}+\varepsilon_{k t}^{i j}$

\section{Application: Trade Potential of CIS Countries}

International trade scholars have discussed how the patterns of trade of the former Soviet Union countries would evolve since the beginning of the transition. Under the command economy, trade patterns were determined largely by planning authorities not by market forces. In addition, the government, following a broader political agenda, shaped economic policy accordingly. For example, it encouraged more trade with countries that shared a similar political system and, on many occasions, prohibited trade with countries that had different political systems. After the government abolished planning and lifted the ideological barriers, it was expected that the Eastern European and former Soviet Union countries would experience a large industrial restructuring and redirection of trade towards wider diversification and higher trade openness. 
Wang and Winters (1991) - who used a sample of 76 market economies to estimate the gravity equation and project a potential for trade of Eastern Europe and the former Soviet Union - predicted a substantial increase in trade with industrialised countries, especially with West Germany and the United States. Gros and Gonciarz (1996) found that Eastern European trade responded very quickly to the new regime by reorientation towards EU markets and, by 1995, did not differ considerably from that of similar Western European countries. At the same time, Havrylyshyn and Al-Atrash (1998) found that the trade of the former Soviet Union countries still was considerably below its potential by the end of the same period. Recently, Babetskaia--Kukharchik and Maurel (2004) estimated that CIS countries, Russia in particular, did not trade up to their potential with the EU and would particularly gain from joining the WTO and improving their market-oriented institutions. However, their approach, based on 'in-sample' projections, makes their findings vulnerable to criticism. That is, perhaps the large deviations of actual trade from that predicted may only show a poor fit of the model rather than deviations from unexploited potential trade. In fact, Egger (2002) argued forcefully that in-sample estimations of the trade potential based on the deviation of residuals from the linear prediction are incorrect because large deviations of residuals in the gravity equation based on the method are not evidence of large deviations of trade from its potential, but rather an indicator of model misspecification.

In this paper, the gravity equation is estimated 'out-of-sample', meaning that it does not include data on trade flows of the CIS countries in the sample 
when calculating parameters of the gravity equation. According to the out-ofsample approach, the gravity equation is estimated for a group of countries that are most integrated into the world trade system and, therefore, operate at the frontier of trade efficiency. The trade potential of a country is calculated based on characteristics of the country, given the out-of-sample estimated coefficients of the gravity equation. This approach was implemented, among others, by McPherson and Trumbull (2008) who used the Hausman--Taylor method to estimate the gravity equation and the out-of-sample method to estimate the unrealized US--Cuban trade potential.

\subsection{Dependent Variable}

In the empirical analysis, we estimated unidirectional bilateral exports for 126 source countries and 157 destination countries in 2000--2006 for each of 10 industries specified in Table $1 .^{7}$ Table 3 presents the definitions of variables and sources of data. Export data in thousands of current US dollars for products of the six-digit harmonized system 1996 classification were initially aggregated to the GTAP sectors using the World Integrated Trade Solution (WITS) software and further aggregated to the industries of the model.

\subsection{Independent Variables}

Data on the industrial composition of GDP in exporting country $i$ at time $t$ is not directly available, which presents a major challenge for a researcher. Therefore,

\footnotetext{
${ }^{7}$ The CIS countries (Armenia, Azerbaijan, Belarus, Georgia, Kyrgyzstan, Kazakhstan, Moldova, Russia, Turkmenistan and Ukraine) are not included in the estimation stage, but their characteristics are used in the prediction stage of the analysis. In addition, Tajikistan and Uzbekistan are excluded due to missing trade data.
} 
we use data on total exports of sector $k$ from country $i$ excluding bilateral exports to country $j$ to construct the closest available proxy,

$s_{k t}^{i}=\frac{\operatorname{export}_{k t}^{i}-\operatorname{export}_{k t}^{i j}}{\operatorname{export}_{t}^{i}}$, which takes into account the time variation in the composition of industrial output. Bilateral export between countries $i$ and $j$ is excluded to deal with the endogeneity of the sector export share. The suggested proxy would represent the output structure of country $i$ reasonably well if

$\frac{Y_{k t}^{i}}{Y_{t}^{i}} \sim \frac{\operatorname{export}_{k t}^{i}}{\text { export }_{t}^{i}}$. Recognizing potential problems and measurement errors related to the suggested proxy, it should be noted that we do not have a better alternative due to data limitations.

GDP in current US dollars and population data were acquired from the 2007 World Development Indicators (WDI). Geographical characteristics and distances between countries were collected from the Centre D'Etudes Prospectives et D'Informations Internationales (CEPII) in Paris. An interior distance was measured as the average distance within a country, and landlocked dummies were chosen to control for trade costs within the source and destination countries. A contiguity dummy (whether one of the countries in the country-pair was ever a colony of the other country and whether countries are located on the same continent) was used to control for pair-specific trade costs that are not directly related to distance. 


\subsection{Selection Variables}

We chose two variables that enter the selection equation, but not the gravity equation, based on the results of Helpman, Melitz and Rubinstein (2008) and Martin and Pham (2008) ${ }^{8}$. The common language dummy is the variable that controls for the pair-specific fixed costs. It captures fixed costs related to adapting to cultural and linguistic barriers between two countries (differences in religious beliefs, translation, advertising etc.).

To control for country-specific fixed costs related to institutional quality in exporting and importing countries, we used governance indicators of regulatory quality acquired from Kaufmann, Kray and Mastruzzi (2007). They capture the effectiveness of bureaucracy, amount of red tape, and quality of policies and regulations that encourage free trade and promote private-sector development. Since data on regulatory quality before 2002 are available on a biennial basis, we approximated the missing values for 2001 by using averages from 2000 and 2002.

\section{Results}

This section has the following goals. First, it reports results from the two-stage estimation of the gravity equation. Second, it discusses how to use the estimated coefficients of the gravity model to predict bilateral trade flows of CIS countries

\footnotetext{
${ }^{8}$ Martin and Pham (2008) employed a Monte-Carlo simulation and demonstrated that ignoring the sample selection problem in the gravity equation (9) leads to substantial biases. They compared various estimation methods, such as truncated OLS, Maximum Likelihood (ML), the Poisson Pseudo Maximum Likelihood (PPML) estimator recommended by Silva and Tenreyro (2006), Nonlinear Least Squares (NLS), and Heckman's Maximum Likelihood (HML), and found that HML produces reliable estimates with small biases and small standard errors.
} 
with each other and the rest of the world. The predicted trade patterns are interpreted as potential trade under the assumption that CIS countries are not too different from a typical country included in the sample. Third, it compares actual trade flows with trade flows predicted by the model and discusses the main findings.

\subsection{Two-stage Estimation of the Gravity Equation}

\subsubsection{Selection equation}

Table 4 presents the results of the probit regression for 10 industries of the model. Importantly, variables that appear only in the selection equation are significant and have the coefficients of the expected sign. The common language within the country-pair that captures pair-specific fixed costs increases the probability of trade quite significantly. Countries that share a common language are more likely to trade in light industry products by 0.21 , motor vehicles and parts by 0.21 , and electronic equipments by 0.26 , while the common language is less important for the probability of positive trade in energy resources and chemical products. Better regulatory qualities in both countries that capture country-specific fixed costs also improve the chances of positive exports. The impact of regulatory quality in country $i$ is greater than in country $j$ across all industries. However, the comparison may be misleading because the model includes destination-country dummies that already incorporate all long-term effects of regulations and institutional quality on the destination country. 
All variables that enter the gravity equation in the second stage are also important determinants of the probability of positive exports. Country $i$ is more likely to export to country $j$ in industry $k$ when it exports more industry $k$ products to other countries, when economies $i$ and $j$ are bigger, and when countries are close to each other. The log of GDP per capita that captures crosscountry differences in production costs and proxies for $w_{k t}^{i}$ has the expected negative effect on the probability of trade. In addition, a common border and, to a lesser extent, being located on the same continent increases the probability of trade in all industries. Countries that have common borders are 0.4 more likely to trade in agriculture, energy, motor vehicles and electronics. Past colonial relationships have a positive and quite uniform impact on the probability of trade across industries; it ranges from 0.2--0.25 in all industries except for manufacture n.e.c. and chemicals, which are 0.12 and 0.17 , respectively.

In addition to the control variables reported in the first column of Table 4, regressions include time and destination-country fixed effects. Since we use nominal GDP and nominal export values, time dummies are included to account for common time shocks and make observations from different time periods comparable (Baldwin and Taglioni, 2006), while destination-country fixed effects correct for variations in price levels. The standard deviations reported in parentheses are cluster robust. Pseudo R-squared reported at the bottom of Table 4 ranges from 0.42 to 0.53 and shows that selected variables explain the probability of export reasonably well. 


\subsubsection{Gravity model of bilateral export corrected for selection and firm-level heterogeneity}

Table 5 reports the results of the evaluation of the gravity equation (13) for each industry estimated on the sample of 126 source countries and 157 destination countries in 2000--2006. We allow for the endogeneity of the log of sector export shares, the log of GDP of the exporting country and its measure of remoteness, and we control for correlations between those variables with unobserved random effects $u^{i j}$ by employing the Hausman--Taylor method that fits panel data random effect models in which some of the explanatory variables are correlated with individual-level unobserved heterogeneity (Hausman and Taylor, 1981). Serlenga and Shin (2007) tested the performance of the Hausman--Taylor method in estimating the gravity equation of bilateral trade flows among 15 European countries in 1960--2001 and found that it provides more sensible results than fixed or random effect methods. Year and destination fixed effects are included, but not reported in the Table 5.

The coefficients of the $\log$ of export share, the $\log$ of GDP $i$ and the $\log$ of GDP $j$ are positive and significant for all sectors, as expected from the theoretical model. At the same time, there is substantial variation in coefficients across industries that justifies the choice of running a separate regression for each industry rather than a pooled regression with industry fixed effects. The $\log$ of distance between countries enters negatively and has substantial crossindustry variability ranging from -0.74 for agriculture and forestry to -1.52 for chemical products. The variables common border, location on the same 
continent and colonial past increase exports for most industries. The coefficients for interior distances have a positive sign for some industries and negative or opposite signs for other industries, which reflects two opposite forces in play higher transportation costs within a country would tend to reduce trade, while larger country size would increase production and demand for certain goods. Landlocked countries tend to trade less due to higher transportation costs (Hummels, 1999; Limao and Venables, 2001). Remoteness of the exporting country has not shown a consistent patter across industries.

$\hat{\psi}_{t}^{i j}=\Phi^{-1}\left(\hat{\rho}_{t}^{i j}\right)$ and its higher powers - variables that approximate $V_{t}^{i j}$ and control for selection in exporters and firm-level heterogeneity - are jointly significant as reported in Table 5 that shows $\chi^{2}(3)$ statistics and the corresponding $\mathrm{p}$-value for the test that all coefficients of the approximating

polynomial, $\sum_{m=1}^{3} b_{k m}\left(\hat{z}_{k t}^{i j}\right)^{m}$, are jointly equal to zero. The sound rejection of the test for all industries indicates the importance of the first-stage selection process in exporters and firm-level heterogeneity on the intensive margins of trade.

In the next section, we use the estimated coefficients of the selection and gravity models to project trade for CIS countries.

\subsection{Trade Structure and Geography of CIS Countries}

A developed model allows us to project the results of the estimation procedure on the sample of CIS countries, which are excluded from the estimation stage, 
along product and space dimensions. We refer to the generated predicted export flows as potential export flows and compare them with actual exports. The structural or geographical divergence of actual trade patterns from potential ones indicates that CIS countries differ from a representative country in the sample in terms of their industrial structure or geographical composition of trade. Based on the magnitude of the divergence, it can be further argued that the CIS region's trade is below or above its potential, albeit with caution due to region-specific characteristics that always make such comparisons susceptible to criticism.

First, we concentrate on the extensive margins and discuss how the actual pattern of CIS positive exports compares with the pattern predicted by the selection equation. The discussion is broken into two parts: the performance of each CIS country along the product dimension and the geographical dimension. Second, we look at the intensive margins and separately discuss performance along industry and geographical dimensions.

\subsubsection{Extensive margins}

Using the sample of CIS countries, we predict the probability of positive trade of each CIS country conditional on its characteristics: $\hat{\rho}_{k t}^{i j}=\operatorname{Prob}\left(\mathrm{X}_{\mathrm{kt}}^{\mathrm{ij}}>0 \mid \Psi_{\mathrm{kt}}^{\mathrm{ij}}\right)$, where $i \in C I S$.

Table 6 reports the ratio of the number of observed positive exports to the number of possible positive exports among CIS countries and their selected trading partners and compares the ratio with the average predicted probability of 
export, $\hat{\rho}^{i j}=\sum_{k=1}^{K} \sum_{t=1}^{T} \hat{\rho}_{k t}^{i j} / K T$. The choice of trading partners is motivated by their importance in both overall world trade and to the CIS region. While each CIS country has its own interesting features, there is an overall tendency to over trade with other CIS countries at the extensive margins. For example, of 630 possible trade links within the CIS region, ${ }^{9}$ Belarus has positive trade in 90 percent of all cases. At the same time, the selection equation predicts the average probability of positive trade between Belarus and other CIS countries at just 27 percent. Belarus and Russia are the only two countries of the CIS region that trade more at the extensive margins with all their trading partners presented in Table 6. Armenia and Turkmenistan trade below their potential, while other countries have patterns that are more complex. The CIS countries tend to under export to large emerging markets such as Brazil, India and China. At the same time, there is a tendency to overtrade with developed markets - EU and US with the exception of the Ukraine, which according to the predictions, should perform better at the extensive margins with all markets but CIS and India.

Looking at the diversification of trade along industrial composition, Table 7 reports the ratio of actual non-zero trade and average predicted probability of trade across industries. Table 7 is split into two large geographical panels, CIS countries (Panel A) and non-CIS countries (Panel B), in order to highlight the

\footnotetext{
${ }^{9}$ Ten industries $x 7$ time periods $x 9$ other CIS countries $=630$. In some instances, we refer to a group of countries such as CIS (10 countries) or EU (27 countries), but the calculations presented in Table 6 are carried out for each member of the group separately and further aggregated to make the presentation of results more compact. Other trading partners are countries such as US, China, India or Brazil.
} 
key differences between trade with other CIS countries and trade with non-CIS countries.

The selection equation consistently under predicts the probability of trade between two CIS countries relative to the actual incidence of positive exports across all industries. At the same time, the selection equation works reasonably well to predict the industrial composition of the extensive margins of exports from CIS countries to non-CIS countries. Based on the results, the trade within the CIS region is well diversified and exceeds the level of diversification that is usually observed in trade between two countries from the sample of 126 exporting countries. The level of industrial diversification of exports to non-CIS countries, on the other hand, generally matches the level predicted by the gravity equation. Smaller countries tend to have more diversified exports than predicted by the model. Belarus is an example of a country that outperforms the predictions of the model in all industries. Ukraine, on the other hand, is an example of a CIS country that consistently underperforms in its trade with nonCIS countries in eight out of ten industries.

\subsubsection{Intensive margins}

We generate predicted exports of CIS countries at the intensive margins by applying the characteristics of CIS countries to the coefficients of the gravity equation (13) that is estimated on the sample of 126 exporting countries. Table 8 reports the geographical distribution of actual and predicted exports at the intensive margins for CIS countries with selected trading partners. For each 
country-pair, the top number is $x_{k}^{i}=\frac{X_{k}^{i}}{X^{i}}$, where $X_{k}^{i}$ is the total actual export of country $i$ in sector $k, X^{i}$ is the total actual export of country $i$ and the bottom number is $\hat{x}_{k}^{i}=\frac{\hat{X}_{k}^{i}}{\hat{X}^{i}}$, where actual exports are replaced by predicted exports. By construction, each row of Table 8 adds up to one.

According to the results, CIS countries from the European region (Belarus, Ukraine and Moldova) underperform in their trade with the EU and over perform in their trade with CIS countries. The CIS countries of Central Asia, the Caucasus region and Russia, on the other hand, tend to overtrade with the EU countries and considerably undertrade with China and India. In particular, Azerbaijan, Kazakhstan, Russia and Turkmenistan export considerably more to the EU countries at the intensive margins than predicted by the gravity equation, which contradicts the pattern at the extensive margins discussed previously. However, Table 9, which presents an industry breakdown of CIS exports at the intensive margins, helps to explain this inconsistency.

The above-mentioned countries have an industrial structure of exports that is extremely skewed towards exports of energy resources. The share of exports of energy resources to total exports of Azerbaijan and Turkmenistan equals 71 percent, while for Kazakhstan and Russia those numbers are 57 and 47 percent, respectively. ${ }^{10}$ Tables 10 and 11 report the geographical and industrial

\footnotetext{
${ }^{10}$ The presented statistics are calculated for a select group of partner countries that includes Brazil, China, 10 CIS countries, 27 EU countries, India and US in 2000--2006. An extended sample would change the numbers slightly, but the reported pattern would remain the same.
} 
breakdowns of exports at the intensive margins, excluding the energy resources sector. After the exclusion of the energy resource industry from our sample, the model fit of the geographical distribution of exports improves considerably. However, Central Asia and the Caucasus region are expected to trade considerably more with China and India at the expense of lowering the EU share of exports.

Table 11 shows the industrial composition of exports at the intensive margins. There are no large and consistent deviations of potential trade from actual (apart from Turkmenistan's exports in timber, wood, pulp and paper, which is clearly an outlier) except for a slight underperformance of almost all CIS countries in exports of agricultural and food products and the over performance of some countries (Kazakhstan and Ukraine, in particular) in the export of metals. These observations lead us to conclude that there are large distortions of trade in the CIS region towards supplying energy resources and metals to the EU. Given the rapid development of China and India, Central Asia and the Caucasus region of the CIS have surprisingly weak trade relations with those countries. Finally, there is some potential for increased exports in the agriculture and food industries.

\section{Conclusions}

We empirically tested the ability of the Helpman, Melitz and Rubinstein (2008) model to explain patterns of exports at the industry level by estimating the gravity model that takes into account the selection and asymmetry biases related to existence of zero-trade flows and firm-level heterogeneity. The model fits the 
data relatively well and demonstrates that the selection equation is an important component of the gravity equation that should be taken into account when estimating trade flows. The model was tested by applying an out-of-sample approach to predict the trade patterns of CIS countries and performed relatively well.

To sum up the findings presented in Tables 6--11, the trade patterns of CIS countries are largely in line with what is expected from the gravity model. The predicted geographical and industrial composition of exports matches the real data quite successfully. This, in turn, indicates that the model developed in the paper is well suited to evaluating trade potential and generating trade structure when the data are lacking.

Nevertheless, there are some important distortions of export flows by CIS countries that indicate smaller degrees of geographical and industrial diversification than would be expected from the model. CIS countries tend to overtrade with other CIS countries and export disproportionally more in resource-extraction-oriented sectors. This is especially true in the energy resource industry, which particularly fails to fit the worldwide pattern. At the same time, CIS countries export consistently less than expected in the agriculture and forestry and the food industries, which might indicate additional external and internal trade barriers that are particular to these two industries. Central Asia and the Caucasus region have surprisingly weak trade connections with China and India and have great potential to increase their eastward exports. 
At the same time, the Ukraine, Belarus and Moldova underperform in their trade with the EU, especially in agriculture and food products.

\section{References}

Anderson, J.E., 1979, A theoretical foundation for the gravity equation, American Economic Review, 69(1), 106-16

Anderson, J.E., van Wincoop, E., 2003. Gravity with Gravitas: A Solution to the Border Puzzle. American Economic Review 93(1), 170--92.

Babetskaia--Kukharchuk, O., Maurel, M., 2004. Russia's Access to the WTO: What Potential for Trade Increase? Journal of Comparative Economics 32(4), 680--699.

Baldwin, R., Taglioni, D., 2006. Gravity for dummies and dummies for gravity equations. NBER Working Paper \#12516.

Chamberlin, E., 1933. The theory of monopolistic competition. Harvard University Press, Cambridge, Mass.

Dixit, A., Stiglitz, J., 1977. Monopolistic Competition and Optimum Product Diversity. American Economic Review 67, 297--308.

Egger, P., 2000. A note on the proper econometric specification of the gravity equation. Economic Letters 66, 25--31.

- 2002. An Econometric View of the Estimation of Gravity Models and the Calculation of Trade Potentials. World Economy 25(2), 297--312.

Feenstra, R., 2003. Advanced International Trade: Theory and Evidence. Princeton University Press, Princeton and Oxford. 
Gros, D., Gonciarz, A., 1996. A note on the trade potential of Central and Eastern Europe. European Journal of Political Economy 12(4), 709--721. Harrison, G., Rutherford, T., Tarr, D., 1997. Economic implications for Turkey of a Customs Union with the European Union. European Economic Review 41(3-5), Paper and Proceedings of the Eleventh Annual Congress of the European Economic Association, pp. 861--870.

Hausman, J.A., Taylor W.E., 1981. Panel Data and Unobservable Individual Effect. Econometrica 49, 1377--1398.

Havrylyshyn, O., Al-Atrash, H., 1998. Opening Up and Geographic Diversification of Trade in Transition Economies. IMF Working Paper No. 98/22, Available at SSRN: $\underline{\text { http://ssrn.com/abstract }=882252}$.

Helpman, E., Melitz, M., Rubinstein, Y., 2008. Estimating Trade Flows: Trading Partners and Trading Volumes. Quarterly Journal of Economics 123(2), 441--487.

Hummels, David, 1999. Toward a Geography of Trade Costs. Available at SSRN: $\underline{\text { http://ssrn.com/abstract=160533. }}$.

Kaufmann, D., Kraay, A., Mastruzzi, M., 2007. Governance Matters VI:

Governance Indicators for 1996--2006. World Bank Policy Research Working Paper No. 4280, Available at SSRN:

http://ssrn.com/abstract=999979.

Krugman P., 1979. Increasing Returns, Monopolistic Competition, and International Trade. Journal of International Economics 9, 469--79. 
Limão, N., Venables, A., 2001. Infrastructure, Geographical Disadvantage, Transport Costs, and Trade. The World Bank Economic Review 15(3), 451.

Martin, W., Pham, C., 2008. Estimating the Gravity Equation when Zero Trade Flows are Frequent. unpublished manuscript.

Manova, K., 2006. Credit Constraints, Heterogeneous Firms and International Trade. Available at SSRN: $\underline{\text { http://ssrn.com/abstract }=952552}$.

McCallum, J., 1995. National Borders Matter: Canada-U.S. Regional Trade Patterns. American Economic Review 85(3), 615--623.

McPherson, M., Trumbull, W., 2008. Rescuing Observed Fixed Effects: using the Hausman-Taylor Method for Out-of-Sample Trade Projections. The International Trade Journal 22(3), 315--340.

Melitz, M., 2003, The impact of trade on intra-industry reallocation and aggregate industry productivity, Econometrica, 71(6), 1695--1725.

Rose, A., 2000. One Money One Market: Estimating the Effect of Common Currencies on Trade. Economic Policy 15, 7--46.

Rutherford, T., Tarr, D., 2008. Poverty effects of Russia's WTO accession: Modeling "real" households with endogenous productivity effects. Journal of International Economics 75(1), 131--150.

Serlenga, L., Shin, Y., 2007. Gravity Models of Intra-EU Trade: application of the CCEP-HT estimation in heterogeneous panels with unobserved common time specific factors. Journal of Applied Econometrics 22(2), 361--381. 
Silva, J., Tenreyro, S., 2006. The Log of Gravity. The Review of Economics and Statistics 88(4), 641--658.

Tinbergen, J., 1962. Shaping the World Economy: Suggestions for an International Economic Policy. Twentieth Century Fund, New York.

Wang, Z., Winters, L., 1991. The Trading Potential of Eastern Europe. CEPR

Discussion Paper no. 610. London, Centre for Economic Policy

Research, http://www.cepr.org/pubs/dps/DP610.asp. 
Table 1 Concordances between GTAP sectors and industries of the model

\begin{tabular}{|c|c|c|c|}
\hline $\begin{array}{l}\text { GTAP } \\
\text { sector }\end{array}$ & Description & $\begin{array}{l}\text { Sector of the } \\
\text { model }\end{array}$ & Description \\
\hline$\overline{1}$ & Paddy rice & 1 & Agriculture and forestry \\
\hline 2 & Wheat & 1 & Agriculture and forestry \\
\hline 3 & Cereal grains nec & 1 & Agriculture and forestry \\
\hline 4 & Vegetables, fruit, nuts & 1 & Agriculture and forestry \\
\hline 5 & Oil seeds & 1 & Agriculture and forestry \\
\hline 6 & Sugar cane, sugar beet & 1 & Agriculture and forestry \\
\hline 7 & Plant-based fibers & 1 & Agriculture and forestry \\
\hline 8 & Crops nec & 1 & Agriculture and forestry \\
\hline 9 & Bovine cattle, sheep and goats, horses & 1 & Agriculture and forestry \\
\hline 10 & Animal products nec & 1 & Agriculture and forestry \\
\hline 11 & Raw milk & 1 & Agriculture and forestry \\
\hline 12 & Wool, silk-worm cocoons & 1 & Agriculture and forestry \\
\hline 13 & Forestry & 1 & Agriculture and forestry \\
\hline 14 & Fishing & 1 & Agriculture and forestry \\
\hline 15 & Coal & 2 & Energy resources \\
\hline 16 & Oil & 2 & Energy resources \\
\hline 17 & Gas & 2 & Energy resources \\
\hline 18 & Minerals nec & 2 & Energy resources \\
\hline 19 & Bovine meat products & 3 & Food industry \\
\hline 20 & Meat products nec & 3 & Food industry \\
\hline 21 & Vegetable oils and fats & 3 & Food industry \\
\hline 22 & Dairy products & 3 & Food industry \\
\hline 23 & Processed rice & 3 & Food industry \\
\hline 24 & Sugar & 3 & Food industry \\
\hline 25 & Food products nec & 3 & Food industry \\
\hline 26 & Beverages and tobacco products & 3 & Food industry \\
\hline 27 & Textiles & 4 & Light industry \\
\hline 28 & Wearing apparel & 4 & Light industry \\
\hline 29 & Leather products & 4 & Light industry \\
\hline 30 & Wood products & 5 & Timber, wood, pulp and paper \\
\hline 31 & Paper products, publishing & 5 & Timber, wood, pulp and paper \\
\hline 32 & Petroleum, coal products & 6 & Chemicals and petrochemicals \\
\hline 33 & Chemical, rubber, plastic products & 6 & Chemicals and petrochemicals \\
\hline 34 & Mineral products nec & 6 & Chemicals and petrochemicals \\
\hline 35 & Ferrous metals & 7 & Metallurgy \\
\hline 36 & Metals nec & 7 & Metallurgy \\
\hline 37 & Metal products & 7 & Metallurgy \\
\hline 38 & Motor vehicles and parts & 8 & Motor vehicles and parts \\
\hline 39 & Transport equipment nec & 8 & Motor vehicles and parts \\
\hline 40 & Electronic equipment & 9 & Electronic equipment \\
\hline 41 & Machinery and equipment nec & 10 & Manufactures nec \\
\hline 42 & Manufactures nec & 10 & Manufactures nec \\
\hline
\end{tabular}


Table 2 Export summary statistics

\begin{tabular}{|c|c|c|c|}
\hline Industry & $\begin{array}{c}\text { Average export, } \\
\text { thousands of } \\
\text { current \$US }\end{array}$ & $\begin{array}{l}\text { Number } \\
\text { observed } \\
\text { positive }\end{array}$ & $\begin{array}{l}\text { Share of number of } \\
\text { positive exports to } \\
\text { number of potential }\end{array}$ \\
\hline Agriculture and forestry & 22803.9 & 60133 & 0.40 \\
\hline Energy resources & 105045.0 & 37752 & 0.25 \\
\hline Food industry & 39195.9 & 69004 & 0.46 \\
\hline Light industry & 53032.5 & 68337 & 0.46 \\
\hline Timber, wood, and paper & 32624.4 & 69211 & 0.47 \\
\hline $\begin{array}{ll}\text { Chemicals } & \text { and } \\
\text { petrochemicals } & \end{array}$ & 118497.5 & 78114 & 0.53 \\
\hline Metallurgy & 64446.3 & 67341 & 0.45 \\
\hline Motor vehicles and parts & 121924.2 & 59105 & 0.40 \\
\hline Electronic equipment & 137174.2 & 58997 & 0.40 \\
\hline Manufactures nec & 130213.5 & 78444 & 0.53 \\
\hline Overall & 82039.6 & 646438 & 0.44 \\
\hline
\end{tabular}

Note: Number of potential positive export links is calculated under assuption that within an industry all source countries trade with all destination countries 
Table 3 Definition of variables and data sources

Variables

Export from $i$ to $j$ in sector $k$, in thousands of current \$US. COMTRADE exports data aggregated to GTAP sectors are calculated United Nations Commodity based on HS1996 classification in 2000-2006 - CIS excluded - and further aggregated to industries of the model.

\section{Independent variables}

Sector export share

GDP

(Total export of country i in industry $\mathrm{k}$ - export from $\mathrm{i}$ to $\mathrm{j}$ in industry $\mathrm{k}$ )/Total export of country

Population

Gross domestic product, in current $\$ \cup S$.

Population

Author's calculations

Interior distance

Internal distance of country, (an often used measure of average distance between producers and consumers in a country, se World development indicators Head and Mayer, 2002, "Illusory Border Effects", CEPII Working Paper No. 2002-01, for more on this topic).

World development indicators

$$
d_{i i}=0.67 \sqrt{\text { area/ } \pi}
$$

distance between the biggest cities of countries i and j. dkl is the distance between cities $\mathrm{k}$ and I. (Head and Mayer, 2002)

$$
d_{i j}=\sum_{k \in i}\left(\text { pop }_{k} / p o p_{i}\right) \sum_{l \in j}\left(\text { pop }_{l} / \operatorname{pop}_{j}\right) d_{k l}
$$

Landlocked Dummy variable set equal to 1 for landlocked countries.

$$
M R T_{j_{t}}=\ln \left(\sum_{k=1, \pi_{j}>0}^{c} \frac{G D_{D_{k}}}{d i s f_{k}}\right)
$$

Colony

Same continent

Dummy variable set equal to 1 if one of the countries used to be a colony of the other country.

Dummy variable set equal to 1 if countries $i$ and $j$ located on the same continent. Mapping of countries to continents was taken

CEPII from CEPII 
Table 4 Selection equation - marginal effects

\begin{tabular}{|c|c|c|c|c|c|c|c|c|c|c|}
\hline & 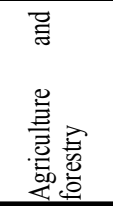 & 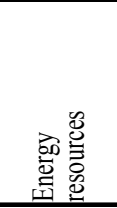 & 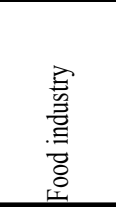 & 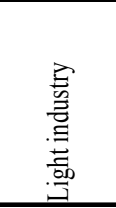 & 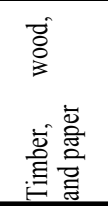 & 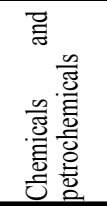 & 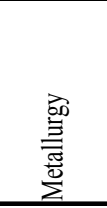 & 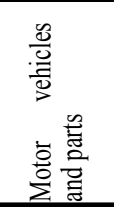 & 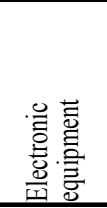 & 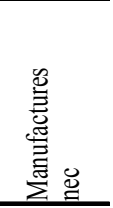 \\
\hline \multirow[t]{2}{*}{ Sector export share } & $0.11^{* *}$ & $0.023^{* *}$ & $0.12^{* *}$ & $0.099 * *$ & $0.10^{* *}$ & $0.056^{* *}$ & $0.061^{* *}$ & $0.094 * *$ & $0.094 * *$ & $0.12 * *$ \\
\hline & $(0.003)$ & $(0.001)$ & $(0.004)$ & $(0.003)$ & $(0.003)$ & $(0.003)$ & $(0.003)$ & $(0.003)$ & $(0.002)$ & $(0.003)$ \\
\hline \multirow{2}{*}{ Common lang. Yes=1 } & $0.21 * *$ & $0.13^{* *}$ & $0.17^{* *}$ & $0.21^{* *}$ & $0.22 * *$ & $0.13^{* *}$ & $0.18^{* *}$ & $0.25^{* *}$ & $0.26^{* *}$ & $0.18^{* *}$ \\
\hline & $(0.012)$ & $(0.012)$ & $(0.011)$ & $(0.011)$ & $(0.009)$ & $(0.009)$ & $(0.011)$ & $(0.012)$ & $(0.012)$ & $(0.008)$ \\
\hline \multirow[t]{2}{*}{ Reg. quality i } & $0.082^{* *}$ & $0.18^{* *}$ & $0.12^{* *}$ & $0.10^{* *}$ & $0.080^{* *}$ & $0.15^{* *}$ & $0.14^{* *}$ & $0.15^{* *}$ & $0.13^{* *}$ & $0.069^{* *}$ \\
\hline & $(0.008)$ & $(0.008)$ & $(0.008)$ & $(0.007)$ & $(0.007)$ & $(0.007)$ & $(0.008)$ & $(0.009)$ & $(0.010)$ & $(0.007)$ \\
\hline \multirow[t]{2}{*}{ Reg. quality $\mathrm{j}$} & $0.054^{* *}$ & 0.015 & $0.044^{* *}$ & $0.047^{* *}$ & $0.048^{* *}$ & $0.031^{* *}$ & $0.045^{* *}$ & $0.056^{* *}$ & $0.037 * *$ & $0.045^{* *}$ \\
\hline & $(0.012)$ & $(0.009)$ & $(0.011)$ & $(0.012)$ & $(0.012)$ & $(0.010)$ & $(0.012)$ & $(0.013)$ & $(0.014)$ & $(0.010)$ \\
\hline \multirow[t]{2}{*}{ Log of distance } & $-0.055^{* *}$ & $-0.14^{* *}$ & $-0.092^{* *}$ & $-0.053^{* *}$ & $-0.079^{* *}$ & $-0.053^{* *}$ & $-0.096^{* *}$ & $-0.10^{* *}$ & $-0.065^{* *}$ & $-0.038^{* *}$ \\
\hline & $(0.011)$ & $(0.009)$ & $(0.013)$ & $(0.012)$ & $(0.012)$ & $(0.011)$ & $(0.013)$ & $(0.013)$ & $(0.014)$ & $(0.011)$ \\
\hline \multirow[t]{2}{*}{ Log of GDP per capita i } & $-0.11^{* *}$ & -0.089 ** & $-0.061^{* *}$ & $-0.052^{* *}$ & $-0.067^{* *}$ & $-0.057 * *$ & $-0.068^{* *}$ & $-0.069^{* *}$ & -0.0026 & $-0.017^{* *}$ \\
\hline & $(0.006)$ & $(0.005)$ & $(0.005)$ & $(0.006)$ & $(0.005)$ & $(0.005)$ & $(0.006)$ & $(0.006)$ & $(0.006)$ & $(0.004)$ \\
\hline \multirow[t]{2}{*}{ Log of GDP i } & $0.25^{* *}$ & $0.13^{* *}$ & $0.24 * *$ & $0.22 * *$ & $0.23^{* *}$ & $0.20^{* *}$ & $0.27^{* *}$ & $0.22 * *$ & $0.17^{* *}$ & $0.15^{* *}$ \\
\hline & $(0.005)$ & $(0.003)$ & $(0.005)$ & $(0.005)$ & $(0.005)$ & $(0.004)$ & $(0.006)$ & $(0.006)$ & $(0.006)$ & $(0.004)$ \\
\hline \multirow[t]{2}{*}{ Log of GDP $j$} & $0.048^{* *}$ & $0.037^{* *}$ & $0.023^{*}$ & $0.030^{*}$ & $0.026^{*}$ & $0.024^{*}$ & $0.032^{* *}$ & $0.051^{* *}$ & -0.014 & 0.019 \\
\hline & $(0.012)$ & $(0.009)$ & $(0.011)$ & $(0.011)$ & $(0.012)$ & $(0.009)$ & $(0.011)$ & $(0.013)$ & $(0.014)$ & $(0.010)$ \\
\hline \multirow[t]{2}{*}{ Contig. Yes=1 } & $0.41^{* *}$ & $0.40^{* *}$ & $0.33^{* *}$ & $0.34^{* *}$ & $0.30^{* *}$ & $0.22^{* *}$ & $0.32^{* *}$ & $0.41^{* *}$ & $0.41^{* *}$ & $0.22 * *$ \\
\hline & $(0.025)$ & $(0.041)$ & $(0.019)$ & $(0.019)$ & $(0.023)$ & $(0.018)$ & $(0.024)$ & $(0.026)$ & $(0.023)$ & $(0.014)$ \\
\hline \multirow[t]{2}{*}{ Same cont. Yes=1 } & $0.19^{* *}$ & $0.064^{* *}$ & $0.14^{* *}$ & $0.19^{* *}$ & $0.18^{* *}$ & $0.15^{* *}$ & $0.15^{* *}$ & $0.18^{* *}$ & $0.21^{* *}$ & $0.14^{* *}$ \\
\hline & $(0.012)$ & $(0.011)$ & $(0.012)$ & $(0.011)$ & $(0.011)$ & $(0.010)$ & $(0.012)$ & $(0.012)$ & $(0.013)$ & $(0.009)$ \\
\hline \multirow[t]{2}{*}{ Colony Yes=1 } & $0.24 * *$ & $0.25^{* *}$ & $0.23^{* *}$ & $0.24^{* *}$ & $0.20^{* *}$ & $0.17^{* *}$ & $0.20^{* *}$ & $0.24^{* *}$ & $0.20^{* *}$ & $0.12^{*}$ \\
\hline & $(0.062)$ & $(0.041)$ & $(0.064)$ & $(0.063)$ & $(0.056)$ & $(0.047)$ & $(0.058)$ & $(0.067)$ & $(0.054)$ & $(0.059)$ \\
\hline \multirow[t]{2}{*}{ Ln Int. dist i } & $-0.074 * *$ & $0.014^{* *}$ & $-0.048^{* *}$ & $-0.042 * *$ & $-0.081 * *$ & $-0.070^{* *}$ & $-0.096 * *$ & $-0.056^{* *}$ & $0.014^{*}$ & -0.0056 \\
\hline & $(0.006)$ & $(0.005)$ & $(0.006)$ & $(0.006)$ & $(0.006)$ & $(0.005)$ & $(0.006)$ & $(0.006)$ & $(0.007)$ & $(0.005)$ \\
\hline \multirow[t]{2}{*}{ Ln Int. dist $\mathrm{j}$} & $0.14^{* *}$ & $0.11^{* *}$ & $0.18^{* *}$ & $0.16^{* *}$ & $0.18^{* *}$ & $0.12^{* *}$ & $0.14^{* *}$ & $0.10^{* *}$ & $0.29^{* *}$ & $0.15^{* *}$ \\
\hline & $(0.037)$ & $(0.023)$ & $(0.039)$ & $(0.038)$ & $(0.039)$ & $(0.034)$ & $(0.035)$ & $(0.038)$ & $(0.040)$ & $(0.038)$ \\
\hline \multirow[t]{2}{*}{ Landlocked i. Yes=1 } & 0.0090 & -0.0021 & -0.0091 & $0.026^{* *}$ & $0.065^{* *}$ & $0.079^{* *}$ & $0.053^{* *}$ & $0.086^{* *}$ & $0.094 * *$ & $0.089^{* *}$ \\
\hline & $(0.010)$ & $(0.010)$ & $(0.010)$ & $(0.010)$ & $(0.010)$ & $(0.008)$ & $(0.011)$ & $(0.012)$ & $(0.012)$ & $(0.007)$ \\
\hline \multirow[t]{2}{*}{ Landlocked j. Yes=1 } & $-0.38^{* *}$ & $-0.27^{* *}$ & $-0.54^{* *}$ & -0.14 & -0.059 & $-0.17^{*}$ & $-0.18 *$ & $-0.37^{* *}$ & $-0.51^{* *}$ & $-0.41^{* *}$ \\
\hline & $(0.088)$ & $(0.026)$ & $(0.096)$ & $(0.081)$ & $(0.083)$ & $(0.080)$ & $(0.084)$ & $(0.090)$ & $(0.068)$ & $(0.153)$ \\
\hline Chi-squared & 6010.3 & 4651.6 & 5080.8 & 5627.6 & 5906.2 & 5327.1 & 5172.4 & 5721.0 & 6915.3 & 5498.8 \\
\hline Pseudo R-squared & 0.42 & 0.44 & 0.43 & 0.45 & 0.45 & 0.44 & 0.47 & 0.49 & 0.53 & 0.49 \\
\hline Observations & 107091 & 106800 & 107091 & 106659 & 106232 & 106232 & 106232 & 105514 & 104510 & 106231 \\
\hline
\end{tabular}


Table 5 Gravity model of export estimated by Hausman-Taylor method

\begin{tabular}{|c|c|c|c|c|c|c|c|c|c|c|}
\hline & 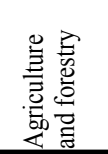 & 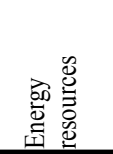 & 总 & 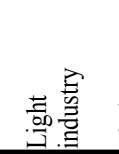 & 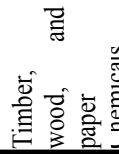 & 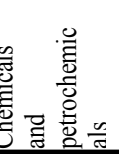 & 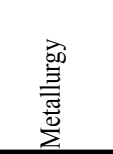 & 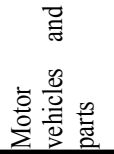 & 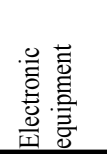 & 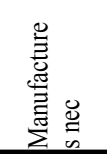 \\
\hline \multirow[t]{2}{*}{ Log of sector exp. share } & $0.21^{* *}$ & $0.12 * *$ & $0.26^{* *}$ & $0.39^{* *}$ & $0.33^{* *}$ & $0.35^{* *}$ & $0.24 * *$ & $0.33^{* *}$ & $0.26^{* *}$ & $0.15^{* *}$ \\
\hline & $(0.050)$ & $(0.022)$ & $(0.041)$ & $(0.037)$ & $(0.046)$ & $(0.023)$ & $(0.032)$ & $(0.034)$ & $(0.039)$ & $(0.050)$ \\
\hline \multirow[t]{2}{*}{ Log of GDP i } & $0.57^{* *}$ & $0.71^{* *}$ & $0.76^{* *}$ & $0.83^{* *}$ & $0.64 * *$ & $0.95^{* *}$ & $0.80^{* *}$ & $0.88^{* *}$ & $0.99 * *$ & $0.68^{* *}$ \\
\hline & $(0.082)$ & $(0.063)$ & $(0.071)$ & $(0.073)$ & $(0.085)$ & $(0.051)$ & $(0.081)$ & $(0.073)$ & $(0.082)$ & $(0.064)$ \\
\hline \multirow{2}{*}{ Log of GDP $j$} & $0.44^{* *}$ & $0.39 * *$ & $0.50^{* *}$ & $0.43^{* *}$ & $0.48^{* *}$ & $0.48^{* *}$ & $0.73 * *$ & $0.59 * *$ & $0.59^{* *}$ & $0.52^{* *}$ \\
\hline & $(0.047)$ & $(0.066)$ & $(0.035)$ & $(0.037)$ & $(0.039)$ & $(0.030)$ & $(0.041)$ & $(0.048)$ & $(0.041)$ & $(0.032)$ \\
\hline \multirow[t]{2}{*}{ Log of distance } & $-0.74 * *$ & $-1.48 * *$ & $-0.97 * *$ & $-0.84 * *$ & $-1.34 * *$ & $-1.52 * *$ & $-1.33^{* *}$ & $-0.85^{* *}$ & $-0.79 * *$ & $-1.08^{* *}$ \\
\hline & $(0.050)$ & $(0.092)$ & $(0.056)$ & $(0.052)$ & $(0.057)$ & $(0.050)$ & $(0.057)$ & $(0.060)$ & $(0.060)$ & $(0.048)$ \\
\hline \multirow[t]{2}{*}{ Contig. Yes $=1$} & $1.19^{* *}$ & $0.67^{*}$ & $1.34 * *$ & $1.34 * *$ & 0.28 & $1.14^{* *}$ & $0.78^{* *}$ & 0.46 & 0.34 & 0.20 \\
\hline & $(0.275)$ & $(0.269)$ & $(0.228)$ & $(0.242)$ & $(0.249)$ & $(0.191)$ & $(0.220)$ & $(0.239)$ & $(0.253)$ & $(0.214)$ \\
\hline \multirow[t]{2}{*}{ Same cont. Yes=1 } & $0.25^{*}$ & -0.049 & $0.38^{* *}$ & $0.77 * *$ & 0.083 & $0.46^{* *}$ & $0.33^{* *}$ & $0.35^{* *}$ & $0.28 *$ & 0.0038 \\
\hline & $(0.118)$ & $(0.129)$ & $(0.097)$ & $(0.113)$ & $(0.124)$ & $(0.091)$ & $(0.101)$ & $(0.110)$ & $(0.121)$ & $(0.101)$ \\
\hline \multirow[t]{2}{*}{ Colony Yes=1 } & $0.45^{*}$ & $0.62^{*}$ & $0.81^{* *}$ & 0.38 & 0.29 & $0.50^{*}$ & $0.50^{*}$ & -0.024 & 0.14 & 0.21 \\
\hline & $(0.223)$ & $(0.260)$ & $(0.219)$ & $(0.231)$ & $(0.239)$ & $(0.208)$ & $(0.212)$ & $(0.219)$ & $(0.221)$ & $(0.204)$ \\
\hline \multirow[t]{2}{*}{ Ln Int. dist i } & $0.36^{* *}$ & $0.57^{* *}$ & $0.15^{* *}$ & 0.056 & 0.060 & -0.014 & 0.039 & $-0.18^{* *}$ & $-0.47 * *$ & $-0.10^{* *}$ \\
\hline & $(0.037)$ & $(0.063)$ & $(0.037)$ & $(0.035)$ & $(0.041)$ & $(0.037)$ & $(0.045)$ & $(0.042)$ & $(0.042)$ & $(0.032)$ \\
\hline \multirow[t]{2}{*}{ Ln Int. dist j } & $0.40^{* *}$ & $0.64 * *$ & $0.27^{*}$ & $0.57 * *$ & 0.080 & $0.33^{* *}$ & $-0.29 *$ & $-0.72 * *$ & -0.028 & -0.055 \\
\hline & $(0.142)$ & $(0.220)$ & $(0.126)$ & $(0.125)$ & $(0.143)$ & $(0.111)$ & $(0.130)$ & $(0.130)$ & $(0.163)$ & $(0.117)$ \\
\hline \multirow[t]{2}{*}{ Landlocked i, Yes=1 } & $-0.31^{* *}$ & $-1.40^{* *}$ & $-0.57^{* *}$ & $-0.22^{*}$ & $-0.45^{* *}$ & $-0.63^{* *}$ & -0.052 & 0.036 & $-0.29 * *$ & $-0.31^{* *}$ \\
\hline & $(0.082)$ & $(0.144)$ & $(0.088)$ & $(0.087)$ & $(0.091)$ & $(0.089)$ & $(0.094)$ & $(0.097)$ & $(0.098)$ & $(0.084)$ \\
\hline \multirow[t]{2}{*}{ Landlocked j, Yes=1 } & $-2.09^{* *}$ & $-4.68^{* *}$ & -1.02 & $-1.55^{* *}$ & $-2.19^{* *}$ & $-2.65^{* *}$ & $-2.24^{* *}$ & $-3.74 * *$ & -0.44 & 0.0037 \\
\hline & $(0.624)$ & $(0.969)$ & $(0.535)$ & $(0.482)$ & $(0.515)$ & $(0.473)$ & $(0.493)$ & $(0.512)$ & $(0.505)$ & $(0.529)$ \\
\hline \multirow[t]{2}{*}{ Remoteness i } & -0.40 & -0.64 & -0.14 & $0.66^{* *}$ & 0.062 & $0.76^{* *}$ & $0.49^{*}$ & -0.34 & 0.098 & $0.75^{* *}$ \\
\hline & $(0.210)$ & $(0.327)$ & $(0.176)$ & $(0.179)$ & $(0.189)$ & $(0.161)$ & $(0.202)$ & $(0.221)$ & $(0.209)$ & $(0.157)$ \\
\hline \multirow[t]{2}{*}{$\bar{\psi}$} & $0.53 * *$ & 0.11 & $0.35^{* *}$ & $0.31^{*}$ & $0.57^{* *}$ & 0.043 & $0.48 * *$ & $0.46^{* *}$ & $0.64^{* *}$ & $0.75^{* *}$ \\
\hline & $(0.151)$ & $(0.115)$ & $(0.111)$ & $(0.125)$ & $(0.148)$ & $(0.077)$ & $(0.119)$ & $(0.125)$ & $(0.144)$ & $(0.121)$ \\
\hline \multirow[t]{2}{*}{$\psi^{2}$} & $0.26^{* *}$ & $0.34^{* *}$ & $0.22 * *$ & $0.30^{* *}$ & $0.39^{* *}$ & $0.29^{* *}$ & $0.29^{* *}$ & $0.40^{* *}$ & $0.44^{* *}$ & $0.30^{* *}$ \\
\hline & $(0.019)$ & $(0.024)$ & $(0.019)$ & $(0.017)$ & $(0.019)$ & $(0.019)$ & $(0.019)$ & $(0.015)$ & $(0.017)$ & $(0.016)$ \\
\hline \multirow[t]{2}{*}{$\psi^{3}$} & $-0.051^{* *}$ & $-0.058^{* *}$ & $-0.045^{* *}$ & $-0.055^{* *}$ & $-0.063^{* *}$ & $-0.046^{* *}$ & $-0.053^{* *}$ & $-0.061^{* *}$ & $-0.079 * *$ & $-0.046^{* *}$ \\
\hline & $(0.004)$ & $(0.007)$ & $(0.004)$ & $(0.004)$ & $(0.004)$ & $(0.004)$ & $(0.004)$ & $(0.004)$ & $(0.004)$ & $(0.003)$ \\
\hline \multirow{2}{*}{$\begin{array}{c}\chi^{2}(3): b_{1}=0, b_{2}=0, b_{3}=0 \\
\text { p-value }\end{array}$} & 218.77 & 212.73 & 164.05 & 347.88 & 521.19 & 281.44 & 282.3 & 791.95 & 760.98 & 504.44 \\
\hline & 0.000 & 0.000 & 0.000 & 0.000 & 0.000 & 0.000 & 0.000 & 0.000 & 0.000 & 0.000 \\
\hline$\chi^{2}$ & 12469.2 & 5334.9 & 13962.4 & 15714.2 & 16810.9 & 21871.5 & 18746.6 & 17977.3 & 21120.4 & 27426.8 \\
\hline$\sigma_{u}^{2}$ & 2.53 & 3.31 & 2.78 & 2.76 & 2.83 & 2.85 & 2.69 & 2.65 & 2.66 & 2.69 \\
\hline$\sigma_{\mathrm{e}}^{2}$ & 1.20 & 1.45 & 1.10 & 1.11 & 1.19 & 1.07 & 1.27 & 1.33 & 1.28 & 1.08 \\
\hline$\rho$ & 0.82 & 0.84 & 0.86 & 0.86 & 0.85 & 0.88 & 0.82 & 0.80 & 0.81 & 0.86 \\
\hline Observations & 52697 & 33273 & 59887 & 59065 & 59679 & 66292 & 57187 & 50602 & 51001 & 66538 \\
\hline & & & & & & & & & & \\
\hline
\end{tabular}


Table 6 Probability of exporting to selected partners - extensive margins

\begin{tabular}{|c|c|c|c|c|c|c|}
\hline \multirow[b]{2}{*}{ Reporter } & \multicolumn{5}{|c|}{ Partner } & \multirow[b]{2}{*}{ USA } \\
\hline & Brazil & China & CIS & $E U$ & India & \\
\hline \multirow[t]{2}{*}{ Armenia } & 0.04 & 0.59 & 0.54 & 0.43 & 0.34 & 0.94 \\
\hline & 0.25 & 0.71 & 0.28 & 0.36 & 0.58 & 0.75 \\
\hline \multirow[t]{2}{*}{ Azerbaijan } & 0.23 & 0.63 & 0.65 & 0.42 & 0.39 & 0.91 \\
\hline & 0.25 & 0.73 & 0.28 & 0.36 & 0.60 & 0.77 \\
\hline \multirow[t]{2}{*}{ Belarus } & 0.41 & 0.79 & 0.90 & 0.85 & 0.67 & 0.94 \\
\hline & 0.33 & 0.65 & 0.27 & 0.64 & 0.49 & 0.83 \\
\hline \multirow[t]{2}{*}{ Georgia } & 0.06 & 0.54 & 0.73 & 0.50 & 0.30 & 0.94 \\
\hline & 0.21 & 0.70 & 0.26 & 0.33 & 0.56 & 0.74 \\
\hline \multirow[t]{2}{*}{ Kazakhstan } & 0.21 & 1.00 & 0.93 & 0.64 & 0.70 & 1.00 \\
\hline & 0.38 & 0.99 & 0.42 & 0.46 & 0.75 & 0.89 \\
\hline \multirow[t]{2}{*}{ Kyrgyzstan } & 0.01 & 0.97 & 0.67 & 0.33 & 0.69 & 0.89 \\
\hline & 0.15 & 0.93 & 0.25 & 0.25 & 0.52 & 0.67 \\
\hline \multirow[t]{2}{*}{ Moldova } & 0.17 & 0.21 & 0.64 & 0.66 & 0.31 & 0.86 \\
\hline & 0.16 & 0.45 & 0.14 & 0.46 & 0.30 & 0.67 \\
\hline \multirow[t]{2}{*}{ Russia } & 0.94 & 1.00 & 0.91 & 0.98 & 1.00 & 1.00 \\
\hline & 0.86 & 1.00 & 0.90 & 0.91 & 0.97 & 1.00 \\
\hline \multirow[t]{2}{*}{ Turkmenistan } & 0.00 & 0.06 & 0.08 & 0.02 & 0.04 & 0.09 \\
\hline & 0.04 & 0.29 & 0.06 & 0.09 & 0.21 & 0.31 \\
\hline \multirow[t]{2}{*}{ Ukraine } & 0.59 & 0.86 & 0.84 & 0.83 & 0.84 & 0.86 \\
\hline & 0.68 & 0.91 & 0.49 & 0.87 & 0.82 & 0.97 \\
\hline \multirow[t]{2}{*}{ All } & 0.27 & 0.66 & 0.69 & 0.57 & 0.53 & 0.84 \\
\hline & 0.35 & 0.78 & 0.36 & 0.50 & 0.61 & 0.80 \\
\hline
\end{tabular}


Table 7 Probability of exporting by industries - extensive margins

\begin{tabular}{|c|c|c|c|c|c|c|c|c|c|c|}
\hline \multirow[b]{2}{*}{ Reporter } & \multicolumn{10}{|c|}{ Industry } \\
\hline & 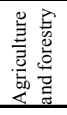 & 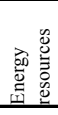 & 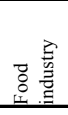 & 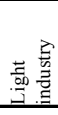 & 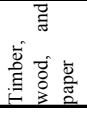 & 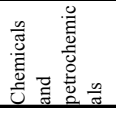 & 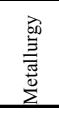 & 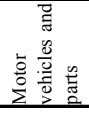 & 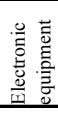 & 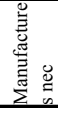 \\
\hline & \multicolumn{10}{|c|}{ Panel A. CIS trading partners } \\
\hline \multirow{2}{*}{ Armenia } & 0.34 & 0.26 & 0.79 & 0.53 & 0.67 & 0.81 & 0.61 & 0.56 & 0.40 & 0.87 \\
\hline & 0.19 & 0.22 & 0.33 & 0.29 & 0.24 & 0.34 & 0.32 & 0.22 & 0.23 & 0.64 \\
\hline \multirow[t]{2}{*}{ Azerbaijan } & 0.71 & 0.41 & 0.81 & 0.64 & 0.61 & 0.89 & 0.61 & 0.61 & 0.47 & 0.81 \\
\hline & 0.33 & 0.26 & 0.32 & 0.25 & 0.25 & 0.45 & 0.32 & 0.33 & 0.19 & 0.34 \\
\hline \multirow[t]{2}{*}{ Belarus } & 0.67 & 0.59 & 0.91 & 1.00 & 1.00 & 1.00 & 1.00 & 1.00 & 0.89 & 1.00 \\
\hline & 0.23 & 0.15 & 0.31 & 0.32 & 0.38 & 0.32 & 0.26 & 0.27 & 0.25 & 0.50 \\
\hline \multirow[t]{2}{*}{ Georgia } & 0.93 & 0.74 & 0.93 & 0.59 & 0.71 & 0.93 & 0.67 & 0.80 & 0.51 & 0.87 \\
\hline & 0.30 & 0.20 & 0.38 & 0.21 & 0.30 & 0.29 & 0.29 & 0.32 & 0.18 & 0.34 \\
\hline \multirow{2}{*}{ Kazakhstan } & 0.90 & 0.93 & 0.99 & 0.79 & 0.91 & 0.99 & 0.97 & 0.93 & 0.89 & 1.00 \\
\hline & 0.46 & 0.34 & 0.41 & 0.39 & 0.34 & 0.55 & 0.53 & 0.41 & 0.44 & 0.57 \\
\hline \multirow[t]{2}{*}{ Kyrgyzstan } & 0.83 & 0.44 & 0.54 & 0.61 & 0.53 & 0.86 & 0.50 & 0.79 & 0.37 & 0.90 \\
\hline & 0.29 & 0.17 & 0.21 & 0.25 & 0.20 & 0.30 & 0.24 & 0.26 & 0.17 & 0.39 \\
\hline \multirow{2}{*}{ Moldova } & 0.79 & 0.33 & 0.96 & 0.60 & 0.79 & 0.90 & 0.64 & 0.51 & 0.43 & 0.96 \\
\hline & 0.22 & 0.10 & 0.24 & 0.20 & 0.14 & 0.15 & 0.10 & 0.12 & 0.07 & 0.18 \\
\hline \multirow[t]{2}{*}{ Russia } & 0.90 & 0.90 & 0.90 & 0.90 & 0.90 & 0.90 & 0.90 & 0.90 & 0.90 & 0.90 \\
\hline & 0.90 & 0.83 & 0.93 & 0.91 & 0.96 & 0.97 & 0.95 & 0.90 & 0.88 & 0.95 \\
\hline \multirow[t]{2}{*}{ Turkmenistan } & 0.14 & 0.09 & 0.07 & 0.10 & 0.03 & 0.14 & 0.04 & 0.07 & 0.00 & 0.10 \\
\hline & 0.17 & 0.05 & 0.04 & 0.14 & 0.00 & 0.13 & 0.03 & 0.07 & 0.02 & 0.03 \\
\hline \multirow[t]{2}{*}{ Ukraine } & 0.81 & 0.83 & 0.86 & 0.86 & 0.86 & 0.86 & 0.86 & 0.86 & 0.84 & 0.86 \\
\hline & 0.50 & 0.35 & 0.60 & 0.49 & 0.57 & 0.59 & 0.59 & 0.48 & 0.41 & 0.65 \\
\hline \multirow[t]{3}{*}{ All } & 0.70 & 0.55 & 0.78 & 0.66 & 0.70 & 0.83 & 0.68 & 0.70 & 0.57 & 0.83 \\
\hline & 0.38 & 0.29 & 0.41 & 0.36 & 0.37 & 0.43 & 0.39 & 0.36 & 0.31 & 0.50 \\
\hline & \multicolumn{10}{|c|}{ Panel B. Non-CIS trading partners } \\
\hline \multirow[t]{2}{*}{ Armenia } & 0.44 & 0.31 & 0.45 & 0.34 & 0.45 & 0.58 & 0.50 & 0.15 & 0.35 & 0.64 \\
\hline & 0.29 & 0.25 & 0.41 & 0.39 & 0.32 & 0.42 & 0.39 & 0.25 & 0.29 & 0.77 \\
\hline \multirow[t]{2}{*}{ Azerbaijan } & 0.52 & 0.26 & 0.37 & 0.41 & 0.43 & 0.71 & 0.46 & 0.30 & 0.30 & 0.61 \\
\hline & 0.48 & 0.30 & 0.36 & 0.33 & 0.31 & 0.53 & 0.39 & 0.39 & 0.19 & 0.49 \\
\hline \multirow[t]{2}{*}{ Belarus } & 0.73 & 0.59 & 0.69 & 0.96 & 0.94 & 0.93 & 0.91 & 0.79 & 0.81 & 0.97 \\
\hline & 0.59 & 0.26 & 0.65 & 0.71 & 0.76 & 0.65 & 0.56 & 0.59 & 0.54 & 0.84 \\
\hline \multirow[t]{2}{*}{ Georgia } & 0.62 & 0.33 & 0.66 & 0.30 & 0.61 & 0.60 & 0.52 & 0.33 & 0.31 & 0.64 \\
\hline & 0.46 & 0.21 & 0.47 & 0.25 & 0.38 & 0.36 & 0.34 & 0.38 & 0.19 & 0.47 \\
\hline \multirow{2}{*}{ Kazakhstan } & 0.71 & 0.66 & 0.42 & 0.57 & 0.55 & 0.83 & 0.83 & 0.60 & 0.60 & 0.83 \\
\hline & 0.59 & 0.39 & 0.43 & 0.45 & 0.38 & 0.58 & 0.57 & 0.42 & 0.44 & 0.64 \\
\hline Kyrgyzstan & 0.63 & 0.15 & 0.29 & 0.46 & 0.26 & 0.49 & 0.43 & 0.37 & 0.29 & 0.53 \\
\hline & 0.42 & 0.16 & 0.23 & 0.29 & 0.22 & 0.34 & 0.26 & 0.27 & 0.17 & 0.51 \\
\hline Moldova & 0.71 & 0.16 & 0.74 & 0.65 & 0.65 & 0.72 & 0.59 & 0.45 & 0.56 & 0.82 \\
\hline & 0.61 & 0.24 & 0.59 & 0.57 & 0.45 & 0.41 & 0.31 & 0.33 & 0.27 & 0.56 \\
\hline Russia & 0.96 & 0.95 & 0.96 & 0.96 & 1.00 & 1.00 & 1.00 & 0.99 & 0.99 & 1.00 \\
\hline & 0.92 & 0.83 & 0.90 & 0.89 & 0.95 & 0.95 & 0.94 & 0.89 & 0.85 & 0.95 \\
\hline Turkmenistan & 0.06 & 0.01 & 0.01 & 0.07 & 0.00 & 0.07 & 0.02 & 0.01 & 0.01 & 0.01 \\
\hline & 0.28 & 0.06 & 0.04 & 0.20 & 0.01 & 0.17 & 0.06 & 0.09 & 0.04 & 0.07 \\
\hline Ukraine & 0.81 & 0.77 & 0.82 & 0.83 & 0.83 & 0.85 & 0.86 & 0.84 & 0.76 & 0.86 \\
\hline & 0.88 & 0.68 & 0.88 & 0.87 & 0.89 & 0.88 & 0.88 & 0.83 & 0.75 & 0.92 \\
\hline All & 0.62 & 0.42 & 0.54 & 0.55 & 0.57 & 0.68 & 0.61 & 0.48 & 0.50 & 0.69 \\
\hline & 0.57 & 0.36 & 0.53 & 0.52 & 0.50 & 0.56 & 0.50 & 0.47 & 0.40 & 0.67 \\
\hline
\end{tabular}


Table 8 Intesive margins of export to selected partners

\begin{tabular}{|c|c|c|c|c|c|c|}
\hline \multirow[b]{2}{*}{ Reporter } & \multicolumn{5}{|c|}{ Partner } & \multirow[b]{2}{*}{ USA } \\
\hline & Brasil & China & CIS & $E U$ & India & \\
\hline \multirow[t]{2}{*}{ Armenia } & 0.000 & 0.013 & 0.258 & 0.602 & 0.001 & 0.126 \\
\hline & 0.004 & 0.055 & 0.281 & 0.479 & 0.033 & 0.148 \\
\hline \multirow[t]{2}{*}{ Azerbaijan } & 0.000 & 0.010 & 0.183 & 0.789 & 0.001 & 0.017 \\
\hline & 0.003 & 0.041 & 0.606 & 0.252 & 0.028 & 0.070 \\
\hline \multirow[t]{2}{*}{ Belarus } & 0.011 & 0.023 & 0.526 & 0.416 & 0.008 & 0.016 \\
\hline & 0.001 & 0.006 & 0.222 & 0.722 & 0.003 & 0.046 \\
\hline \multirow[t]{2}{*}{ Georgia } & 0.001 & 0.008 & 0.619 & 0.308 & 0.011 & 0.053 \\
\hline & 0.002 & 0.025 & 0.675 & 0.230 & 0.014 & 0.054 \\
\hline \multirow[t]{2}{*}{ Kazakhstan } & 0.000 & 0.145 & 0.286 & 0.544 & 0.002 & 0.023 \\
\hline & 0.001 & 0.339 & 0.480 & 0.109 & 0.026 & 0.045 \\
\hline \multirow[t]{2}{*}{ Kyrgyzstan } & 0.000 & 0.104 & 0.658 & 0.210 & 0.003 & 0.026 \\
\hline & 0.003 & 0.494 & 0.188 & 0.201 & 0.044 & 0.070 \\
\hline \multirow[t]{2}{*}{ Moldova } & 0.000 & 0.001 & 0.539 & 0.420 & 0.001 & 0.039 \\
\hline & 0.002 & 0.008 & 0.140 & 0.796 & 0.004 & 0.050 \\
\hline \multirow[t]{2}{*}{ Russia } & 0.004 & 0.078 & 0.136 & 0.725 & 0.013 & 0.044 \\
\hline & 0.002 & 0.234 & 0.160 & 0.478 & 0.023 & 0.103 \\
\hline \multirow[t]{2}{*}{ Turkmenistan } & 0.000 & 0.004 & 0.719 & 0.269 & 0.000 & 0.007 \\
\hline & 0.007 & 0.024 & 0.484 & 0.424 & 0.023 & 0.037 \\
\hline \multirow[t]{2}{*}{ Ukraine } & 0.006 & 0.035 & 0.415 & 0.474 & 0.022 & 0.048 \\
\hline & 0.001 & 0.010 & 0.215 & 0.716 & 0.004 & 0.053 \\
\hline
\end{tabular}


Table 9 Intensive margins of export by industries

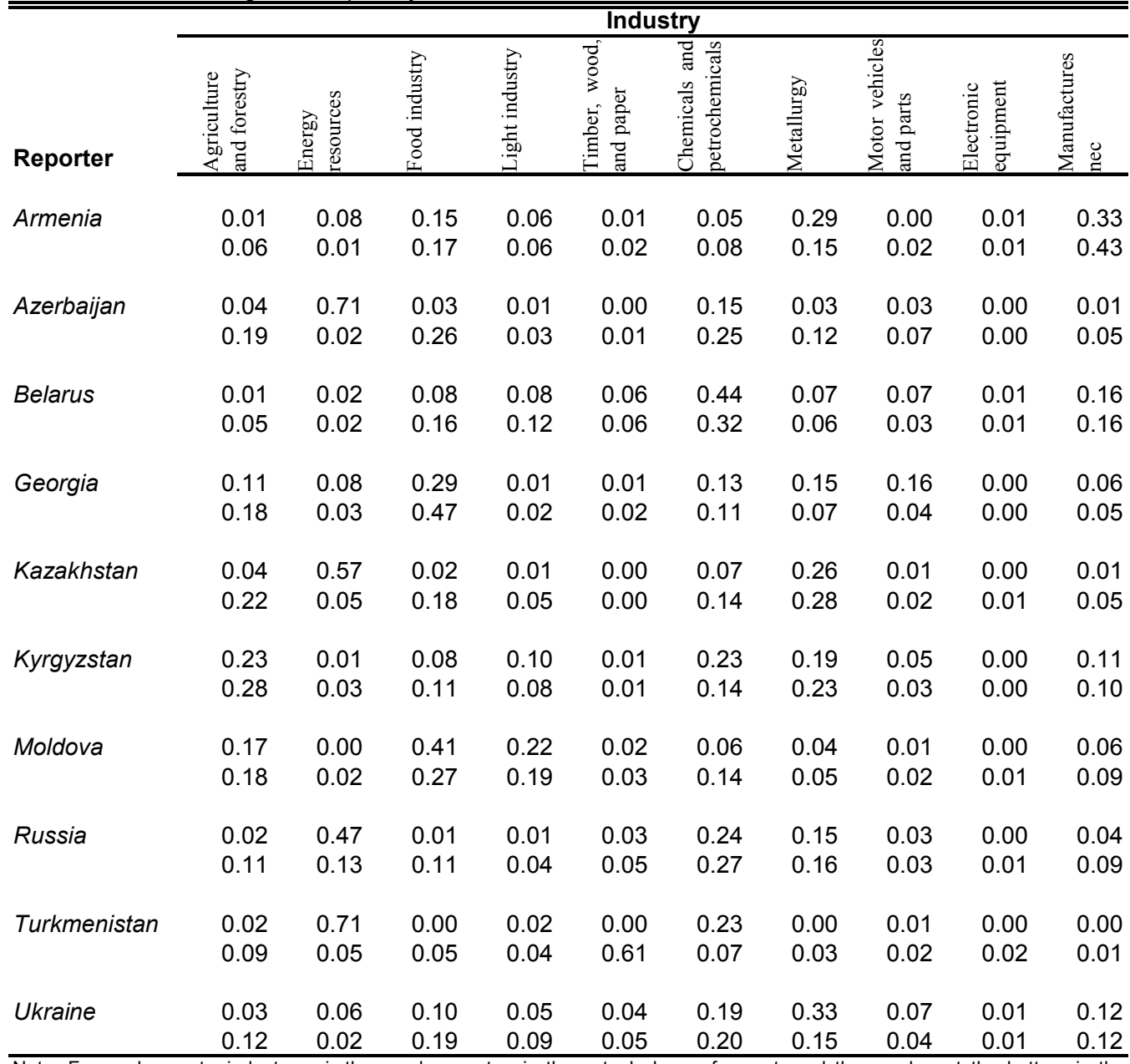

Note: For each country-industry pair the number on top is the actual share of export and the number at the bottom is the predicted share. 
Table 10 Extensive margins of export with selected partners, energy resources excluded

\begin{tabular}{|c|c|c|c|c|c|c|}
\hline \multirow[b]{2}{*}{ Reporter } & \multicolumn{5}{|c|}{ Partner } & \multirow[b]{2}{*}{ USA } \\
\hline & Brasil & China & CIS & $E U$ & India & \\
\hline \multirow[t]{2}{*}{ Armenia } & 0.000 & 0.005 & 0.276 & 0.587 & 0.001 & 0.132 \\
\hline & 0.004 & 0.053 & 0.284 & 0.479 & 0.032 & 0.148 \\
\hline \multirow[t]{2}{*}{ Azerbaijan } & 0.000 & 0.007 & 0.618 & 0.347 & 0.003 & 0.025 \\
\hline & 0.003 & 0.038 & 0.614 & 0.250 & 0.026 & 0.070 \\
\hline \multirow[t]{2}{*}{ Belarus } & 0.012 & 0.024 & 0.537 & 0.403 & 0.008 & 0.017 \\
\hline & 0.001 & 0.005 & 0.222 & 0.724 & 0.002 & 0.046 \\
\hline \multirow[t]{2}{*}{ Georgia } & 0.001 & 0.009 & 0.662 & 0.259 & 0.012 & 0.057 \\
\hline & 0.002 & 0.021 & 0.689 & 0.224 & 0.012 & 0.053 \\
\hline \multirow[t]{2}{*}{ Kazakhstan } & 0.001 & 0.237 & 0.329 & 0.405 & 0.003 & 0.025 \\
\hline & 0.001 & 0.320 & 0.500 & 0.111 & 0.024 & 0.045 \\
\hline \multirow[t]{2}{*}{ Kyrgyzstan } & 0.000 & 0.104 & 0.655 & 0.212 & 0.003 & 0.026 \\
\hline & 0.003 & 0.492 & 0.192 & 0.202 & 0.042 & 0.070 \\
\hline \multirow[t]{2}{*}{ Moldova } & 0.000 & 0.001 & 0.538 & 0.421 & 0.001 & 0.039 \\
\hline & 0.002 & 0.006 & 0.140 & 0.799 & 0.003 & 0.050 \\
\hline \multirow[t]{2}{*}{ Russia } & 0.007 & 0.115 & 0.185 & 0.597 & 0.024 & 0.073 \\
\hline & 0.002 & 0.201 & 0.176 & 0.492 & 0.021 & 0.108 \\
\hline \multirow[t]{2}{*}{ Turkmenistan } & 0.000 & 0.015 & 0.261 & 0.698 & 0.001 & 0.026 \\
\hline & 0.006 & 0.018 & 0.501 & 0.422 & 0.017 & 0.036 \\
\hline \multirow[t]{2}{*}{ Ukraine } & 0.006 & 0.036 & 0.434 & 0.450 & 0.023 & 0.051 \\
\hline & 0.001 & 0.008 & 0.216 & 0.717 & 0.004 & 0.053 \\
\hline
\end{tabular}

Note: For each country-pair the number on top is the actual share of export from country reporter to country partner divided by overall export to all selected partners and the number at the bottom is the share predicted by the gravity equation. Export of energy resources is excluded 
Table 11 Intensive margins of export by industries, energy resource sector excluded

\begin{tabular}{|c|c|c|c|c|c|c|c|c|c|}
\hline \multirow[b]{2}{*}{ Reporter } & \multicolumn{9}{|c|}{ Industry } \\
\hline & 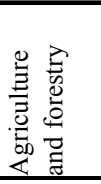 & 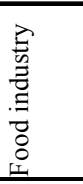 & 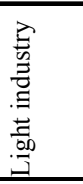 & 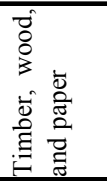 & 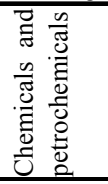 & 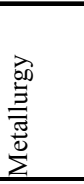 & 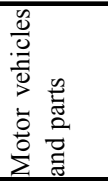 & 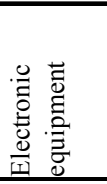 & 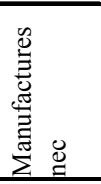 \\
\hline \multirow[t]{2}{*}{ Armenia } & 0.01 & 0.17 & 0.07 & 0.01 & 0.05 & 0.32 & 0.00 & 0.01 & 0.36 \\
\hline & 0.06 & 0.17 & 0.06 & 0.02 & 0.08 & 0.15 & 0.02 & 0.01 & 0.43 \\
\hline \multirow[t]{2}{*}{ Azerbaijan } & 0.13 & 0.10 & 0.02 & 0.00 & 0.51 & 0.09 & 0.11 & 0.00 & 0.03 \\
\hline & 0.20 & 0.26 & 0.03 & 0.01 & 0.26 & 0.12 & 0.07 & 0.00 & 0.05 \\
\hline \multirow[t]{2}{*}{ Belarus } & 0.01 & 0.08 & 0.08 & 0.06 & 0.45 & 0.07 & 0.07 & 0.01 & 0.17 \\
\hline & 0.05 & 0.17 & 0.12 & 0.06 & 0.33 & 0.07 & 0.03 & 0.01 & 0.17 \\
\hline \multirow[t]{2}{*}{ Georgia } & 0.12 & 0.31 & 0.01 & 0.01 & 0.14 & 0.16 & 0.18 & 0.00 & 0.06 \\
\hline & 0.19 & 0.48 & 0.02 & 0.02 & 0.12 & 0.07 & 0.04 & 0.00 & 0.05 \\
\hline \multirow[t]{2}{*}{ Kazakhstan } & 0.10 & 0.04 & 0.02 & 0.00 & 0.17 & 0.61 & 0.02 & 0.00 & 0.03 \\
\hline & 0.23 & 0.19 & 0.05 & 0.01 & 0.14 & 0.30 & 0.02 & 0.01 & 0.05 \\
\hline \multirow[t]{2}{*}{ Kyrgyzstan } & 0.23 & 0.08 & 0.10 & 0.01 & 0.23 & 0.19 & 0.05 & 0.00 & 0.11 \\
\hline & 0.28 & 0.11 & 0.09 & 0.01 & 0.14 & 0.23 & 0.03 & 0.00 & 0.10 \\
\hline \multirow[t]{2}{*}{ Moldova } & 0.17 & 0.41 & 0.22 & 0.02 & 0.06 & 0.04 & 0.01 & 0.00 & 0.06 \\
\hline & 0.19 & 0.28 & 0.19 & 0.03 & 0.14 & 0.05 & 0.02 & 0.01 & 0.09 \\
\hline \multirow[t]{2}{*}{ Russia } & 0.04 & 0.02 & 0.01 & 0.06 & 0.45 & 0.28 & 0.06 & 0.01 & 0.07 \\
\hline & 0.12 & 0.12 & 0.04 & 0.06 & 0.31 & 0.18 & 0.04 & 0.01 & 0.10 \\
\hline \multirow[t]{2}{*}{ Turkmenistan } & 0.08 & 0.01 & 0.07 & 0.00 & 0.80 & 0.00 & 0.03 & 0.00 & 0.00 \\
\hline & 0.09 & 0.05 & 0.04 & 0.64 & 0.07 & 0.03 & 0.02 & 0.02 & 0.02 \\
\hline \multirow[t]{2}{*}{ Ukraine } & 0.04 & 0.10 & 0.06 & 0.04 & 0.20 & 0.35 & 0.07 & 0.01 & 0.13 \\
\hline & 0.12 & 0.19 & 0.09 & 0.05 & 0.20 & 0.16 & 0.05 & 0.01 & 0.13 \\
\hline
\end{tabular}

